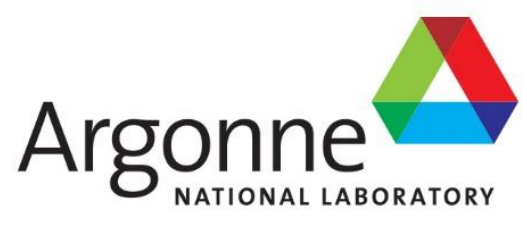

\title{
Regional Resiliency Assessment Program Dependency Analysis Framework
}

Risk and Infrastructure Science Center Global Security Sciences Division 


\begin{abstract}
About Argonne National Laboratory
Argonne is a U.S. Department of Energy laboratory managed by UChicago Argonne, LLC under contract DE-AC02-06CH11357. The Laboratory's main facility is outside Chicago, at 9700 South Cass Avenue, Argonne, Illinois 60439. For information about Argonne and its pioneering science and technology programs, see www.anl.gov.
\end{abstract}

\title{
DOCUMENT AVAILABILITY
}

Online Access: U.S. Department of Energy (DOE) reports produced after 1991 and a growing number of pre-1991 documents are available free via DOE's SciTech Connect (http://www.osti.gov/scitech/).

Reports not in digital format may be purchased by the public from the National Technical Information Service (NTIS):

U.S. Department of Commerce

National Technical Information Service

5301 Shawnee Road

Alexandria, VA 22312

www.ntis.gov

Phone: (800) 553-NTIS (6847) or (703) 605-6000

Fax: (703) 605-6900

Email: orders@ntis.gov

Reports not in digital format are available to DOE and DOE contractors from the Office of Scientific and Technical Information (OSTI):

U.S. Department of Energy

Office of Scientific and Technical Information

P.O. Box 62

Oak Ridge, TN 37831-0062

www.osti.gov

Phone: (865) 576-8401

Fax: (865) 576-5728

Email: reports@osti.gov

\section{Disclaimer}

This report was prepared as an account of work sponsored by an agency of the United States Government. Neither the United States Government nor any agency thereof, nor UChicago Argonne, LLC, nor any of their employees or officers, makes any warranty, express or implied, or assumes any legal liability or responsibility for the accuracy, completeness, or usefulness of any information, apparatus, product, or process disclosed, or represents that its use would not infringe privately owned rights. Reference herein to any specific commercial product, process, or service by trade name, trademark, manufacturer, or otherwise, does not necessarily constitute or imply its endorsement, recommendation, or favoring by the United States Government or any agency thereof. The views and opinions of document authors expressed herein do not necessarily state or reflect those of the United States Government or any agency thereof, Argonne National Laboratory, or UChicago Argonne, LLC. 


\section{Regional Resiliency Assessment Program Dependency Analysis Framework}

by

Frédéric Petit, Duane Verner, and Leslie-Anne Levy

Risk and Infrastructure Science Center, Global Security Sciences Division

Argonne National Laboratory

August 2017 



\section{TABLE OF CONTENTS}

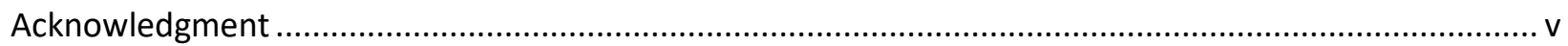

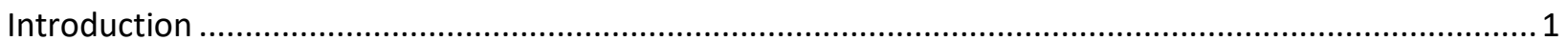

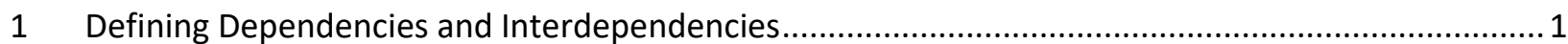

2 Framework for Analyzing Infrastructure Dependencies and Interdependencies ........................... 2

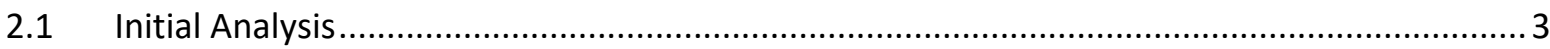

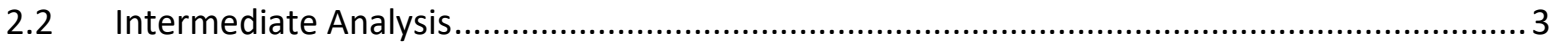

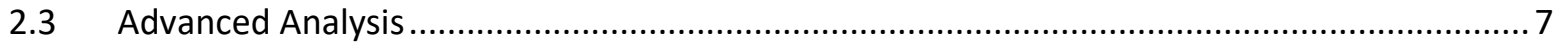

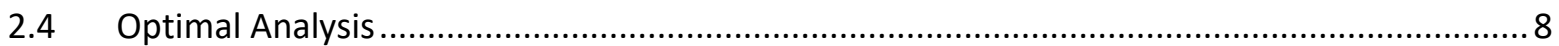

3 Systems Approach to Regional Dependency and Interdependency Analysis ................................9

4 Example Dependency and Interdependency Analyses from Recent RRAP Projects ......................11

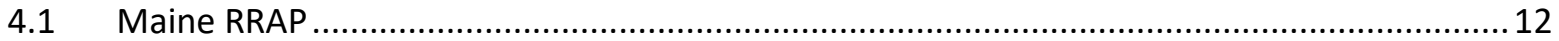

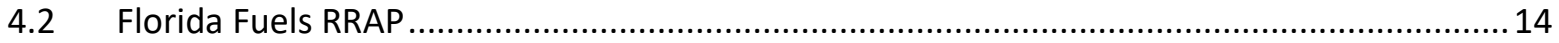

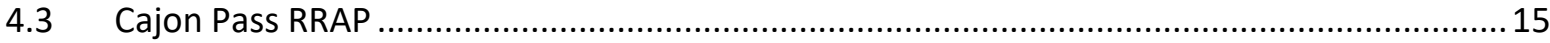

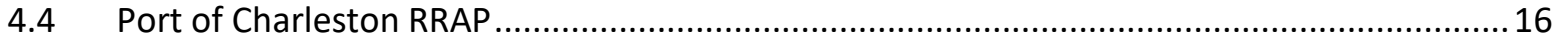

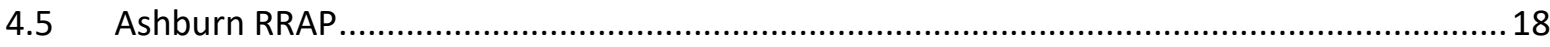

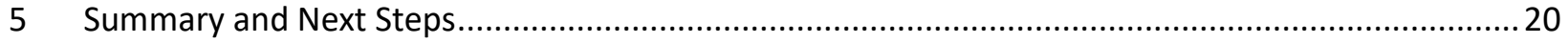

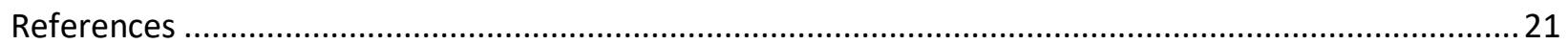

Appendix A: RRAP Project Examples............................................................................... 23 


\section{LIST OF FIGURES}

Figure 1 - Dependency and Interdependency between Two Assets................................................. 1

Figure 2 - Dependency and Interdependency Analysis Framework ........................................................ 4

Figure 3 - Top-down and Bottom-up Approaches to Regional Dependency Analysis ............................. 9

Figure 4 - Possible Effects of the Power Outage Case Study ...............................................................13

Figure 5 - Example of "System of Systems" Modeling and Failure Analysis ............................................14

Figure 6 - Repair and Restoration of a Ruptured Natural Gas Pipeline ...............................................16

Figure 7 - Overview of Upstream Dependencies for Port Terminals ....................................................17

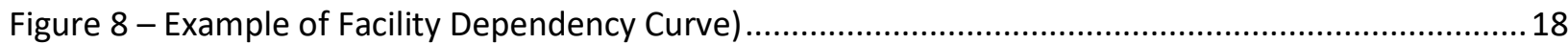

Figure 9 - Cluster of Data Centers in Loudoun County.................................................................... 18

Figure 10 - Beaumeade Circle Data Center Cluster.............................................................................. 19

\section{LIST OF TABLES}

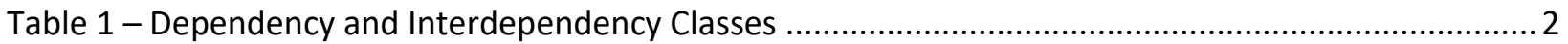

Table 2 - Characteristics of Initial Dependenwcy and Interdependency Analysis ................................... 6

Table 3 - Characteristics of Intermediate Dependency and Interdependency Analysis ...........................6

Table 4 - Characteristics of Advanced Dependency and Interdependency Analysis ................................. 7

Table 5 - Characteristics of Optimal Dependency and Interdependency Analysis .................................. 8

Table 6 - Comparison of Bottom-up and Top-down Approaches .......................................................11

Table 7 - Overall Objectives, Stakeholders, and Infrastructure Systems Addressed in Recent RRAPs......12 
Regional Resiliency Assessment Program Dependency Analysis Framework

LIST OF ACRONYMS

CalOES California Office of Emergency Services

CSA Cyber Security Advisor

DHS U.S. Department of Homeland Security

FDEM Florida Division of Emergency Management

FDLE Florida Department of Law Enforcement

GIS Geographic Information System

IDT Infrastructure Data Taxonomy

MDOT Maine Department of Transportation

MGS Maine Geological Survey

NIPP National Infrastructure Protection Plan

NPPD National Protection and Programs Directorate

PSA Protective Security Advisor

PSCD Protective Security Coordination Division

RRAP Regional Resiliency Assessment Program

SCADA Supervisory Control and Data Acquisition

SCPA South Carolina Ports Authority

SLED South Carolina State Law Enforcement Division

VDEM Virginia Department of Emergency Management 
Regional Resiliency Assessment Program Dependency Analysis Framework

This page left intentionally blank. 


\section{ACKNOWLEDGMENT}

The authors gratefully acknowledge the contributions of many people who helped bring this project to its current state of development, including the Protective Security Coordination Division management team of the U.S. Department of Homeland Security's Office of Infrastructure Protection. More specifically, the authors want to thank Daniel Genua and William McNamara, without whom this work would not have been possible. Their leadership and dedication inspired the Argonne National Laboratory team.

The authors also want to thank their Argonne colleagues who applied the infrastructure dependencies and interdependencies assessment framework in several Regional Resiliency Assessment Program (RRAP) projects. These applications allowed to refine and validate the proposed framework and to provide examples to illustrate this report. 
Regional Resiliency Assessment Program Dependency Analysis Framework

This page left intentionally blank. 


\section{INTRODUCTION}

The purpose of this report is to develop a common understanding and consistent analytic approach for evaluating critical infrastructure dependencies and interdependencies that will inform the programs of the U.S. Department of Homeland Security (DHS) Protective Security Coordination Division (PSCD). The framework outlined here prioritizes a need to tie together top-down and bottom-up analyses ${ }^{1}$ to produce a comprehensive "system of systems" view of dependencies and interdependencies that integrates the best available data. Examples of dependency and interdependency analyses from recent Regional Resiliency Assessment Program (RRAP) projects are included to illustrate practical applications of these concepts in support of infrastructure resilience.

\section{DEFINING DEPENDENCIES AND INTERDEPENDENCIES}

A dependency is a unidirectional relationship between two assets where the operations of one asset affect the operations of the other. For example, a water treatment plant depends upon communications services that support the supervisory control and data acquisition (SCADA) systems required to control plant operations.

An interdependency is a bidirectional relationship between two assets where the operations of both assets affect each other. For example, the water treatment plant requires communications for its SCADA system, and, in turn, provides water used by the communications system to cool its equipment. An interdependency is effectively a combination of two dependencies-therefore, understanding an interdependency requires analysis of the one-way dependencies that comprise it. Figure 1 illustrates the definitions of dependency and interdependency.

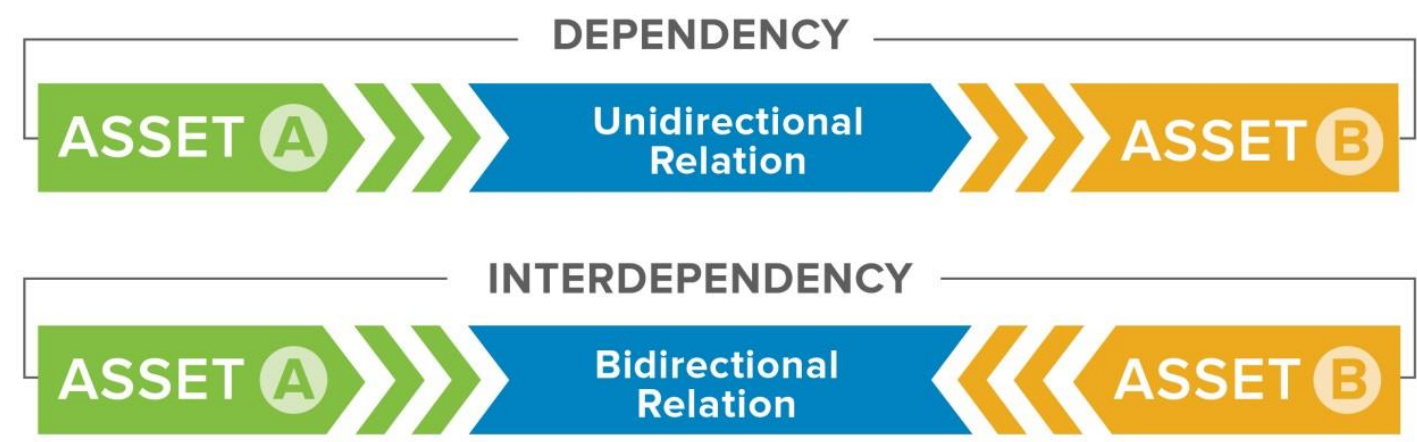

Figure 1 - Dependency and Interdependency between Two Assets (Source: Petit et al. 2015)

To analyze infrastructure dependencies and interdependencies, it is helpful to characterize them based on four distinct classes: physical, cyber, geographic, and logical (Table 1).

1 The National Infrastructure Protection Plan (NIPP) directs the National Protection and Programs Directorate (NPPD) to approach risk management from both a top-down and bottom-up perspective (DHS 2016). 
Table 1 - Dependency and Interdependency Classes (Source: Rinaldi, Peerenboom, and Kelly 2001)

Description
Operations depend on material output(s) of other infrastructure through a
functional and structural linkage between the inputs and outputs of two
assets. In other words, a commodity produced by one infrastructure is needed
as an input by another infrastructure for its operation.

The required data inputs, relevant qualitative and quantitative analytical techniques, and resulting products from dependency and interdependency analyses differ across these four classes. Other dimensions of dependencies and interdependencies that influence the scope and complexity of analysis include:

- Operating environment for critical infrastructure, including broader business, policy, legal, security, safety, and political considerations;

- Coupling and response behavior(s) for critical infrastructure following a disruption;

- Type(s) of failure affecting critical infrastructure;

- Infrastructure characteristics that influence the effects of a disruption; and

- State of operations for critical infrastructure, including normal day-to-day operations, degraded operation, etc.

\section{Framework For ANALYZING INFRASTRUCTURE DePENDENCIES AND INTERDEPENDENCIES}

Assessing infrastructure dependencies and interdependencies to improve regional resilience requires a scalable approach that can be tailored based on decision support needs, stakeholder requirements, and relevant critical infrastructure. Performing dependency and interdependency analyses is not a one-sizefits-all activity. Stakeholder goals, available data, time, budget, and analytical sophistication all combine to influence the scope and complexity of potential dependency analysis. Thus, the overarching concept of this framework is to establish a flexible approach that covers a broad spectrum of options, starting with relatively simple and tightly scoped efforts and culminating in more complex, integrated evaluations. 
The fundamental steps of dependency and interdependency analysis can be distilled into a framework that aligns a four-step continuum of maturity with relevant data inputs, analytical processes, and endproducts. The continuum starts with initial baseline efforts and progresses to an optimal, more holistic approach. Each step in the continuum varies in terms of data required, the type of analysis conducted, and the resulting products. Together, the four steps define a roadmap that can help stakeholders understand and plan for required inputs and desired outputs. Figure 2 summarizes the overall framework, and the sections that follow explore the four steps-initial analysis, intermediate analysis, advanced analysis, and optimal analysis-in greater depth.

\subsection{Initial Analysis}

Initial Analysis consists primarily of researching open source information and involves a limited analysis of infrastructure dependencies and interdependencies. This type of analysis offers a general understanding of the functions of a critical infrastructure asset; however, it does not support an understanding of all dimensions of dependencies nor the visualization of cascading and escalating failures. Table 2 presents an overview of the data, analysis, and products characterizing the Initial Estimate phase.

\subsection{Intermediate Analysis}

In Intermediate Analysis, partners use an evolving set of data collection tools and models that allow for a more detailed analysis of critical infrastructure dependencies and interdependencies. For example, Idaho National Laboratory is piloting a dependency survey tool for use by Protective Security Advisors (PSAs) that uses open source research and service provider interviews in a bottom-up approach to collecting dependency data. ${ }^{2}$ Similarly, Argonne National Laboratory (Argonne) is developing an infrastructure impact analysis tool that takes a top-down approach to integrating and automating the interactions of existing system modeling tools for anticipating cascading and escalating failures (Clifford 2015).

Data collection and analyses are starting to address physical, cyber, and geographic dependencies and to initiate the anticipation and visualization of first-order cascading failures. However, most of the existing tools and models (e.g., EPfast and NGfast) ${ }^{3}$ operate in silos and have little interaction with complementary tools and models. Table 3 presents an overview of the data, analysis, and products characterizing the Intermediate Analysis step.

2 PSAs and Cyber Security Advisors (CSAs) are the core of NPPD's bottom-up approach and serve as the focal point of support to individual critical infrastructure owners and operators (DHS 2016).

3 EPfast is an electric power outage area estimation tool for simulating the behavior of large power systems following power disruptions caused by the loss of power system components. The model explores the possibility of uncontrolled islanding caused by cascading failures and estimates the extent (geographic size) and depth (amount of load shed) of the power outage. NGfast uses progressive, forward pipeline ownership identification and flow quantification processes to track lost flow volumes caused by a pipeline break or curtailment in natural gas supply. Impacts are measured in terms of extent of gas volume disrupted, States affected, utilities affected, number and type of customers affected, and amount of natural-gas-based capacity affected. 


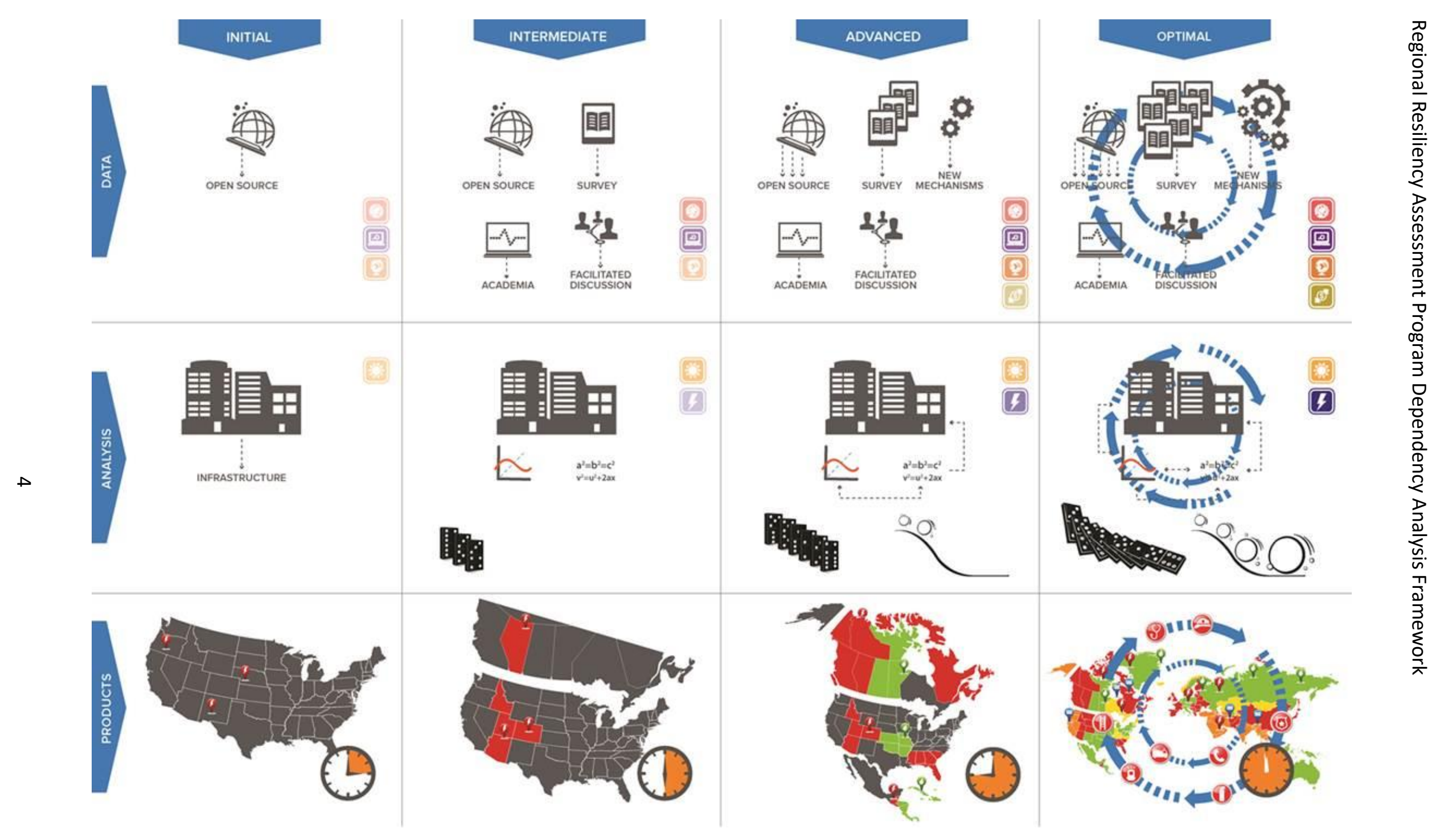

Figure 2 - Dependency and Interdependency Analysis Framework (Source: Petit et al. 2015) 


\section{Figure 2 Legend}

\section{DATA Row}

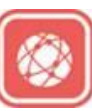

Physical Dependencies

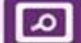

\section{(อ}

Geographic Dependencies

Cyber Dependencies

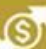

Logical Dependencies

The icon's color intensity indicates the degree of analysis from initial (light color) through optimal (strong color).

Arrows indicate the increase in data sources from using solely open source information at the initial stage through integrating multiple data sources at the optimal stage.

\section{ANALYSIS Row}

\section{Normal Operations}

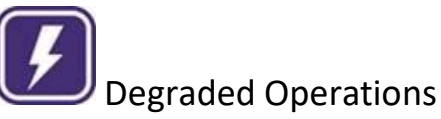

The icon's color intensity indicates the degree of analysis from initial (light color) through optimal (strong color).

Arrows indicate the increase in models' integrations from identification of critical infrastructure at the initial stage through a total integration of modeling capabilities at the optimal stage.

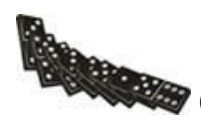

Cascading failures (domino effect)

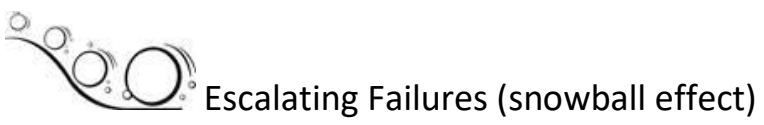

The augmentation of the number of dominoes and snowballs indicates the increase in the complexity of analysis conducted from considering only first-order dependencies at the initial stage through considering several orders of dependencies at the optimal stage.

\section{PRODUCTS ROW}

The different maps indicate the evolution of regional assessment from a general visualization of infrastructure location at the initial stage through an integrated visualization of cascading and escalating failures for all critical infrastructure sectors at the optimal stage.

The clock indicates consideration of the timescale characterizing cascading and escalating failures. 
Table 2 - Characteristics of Initial Dependency and Interdependency Analysis

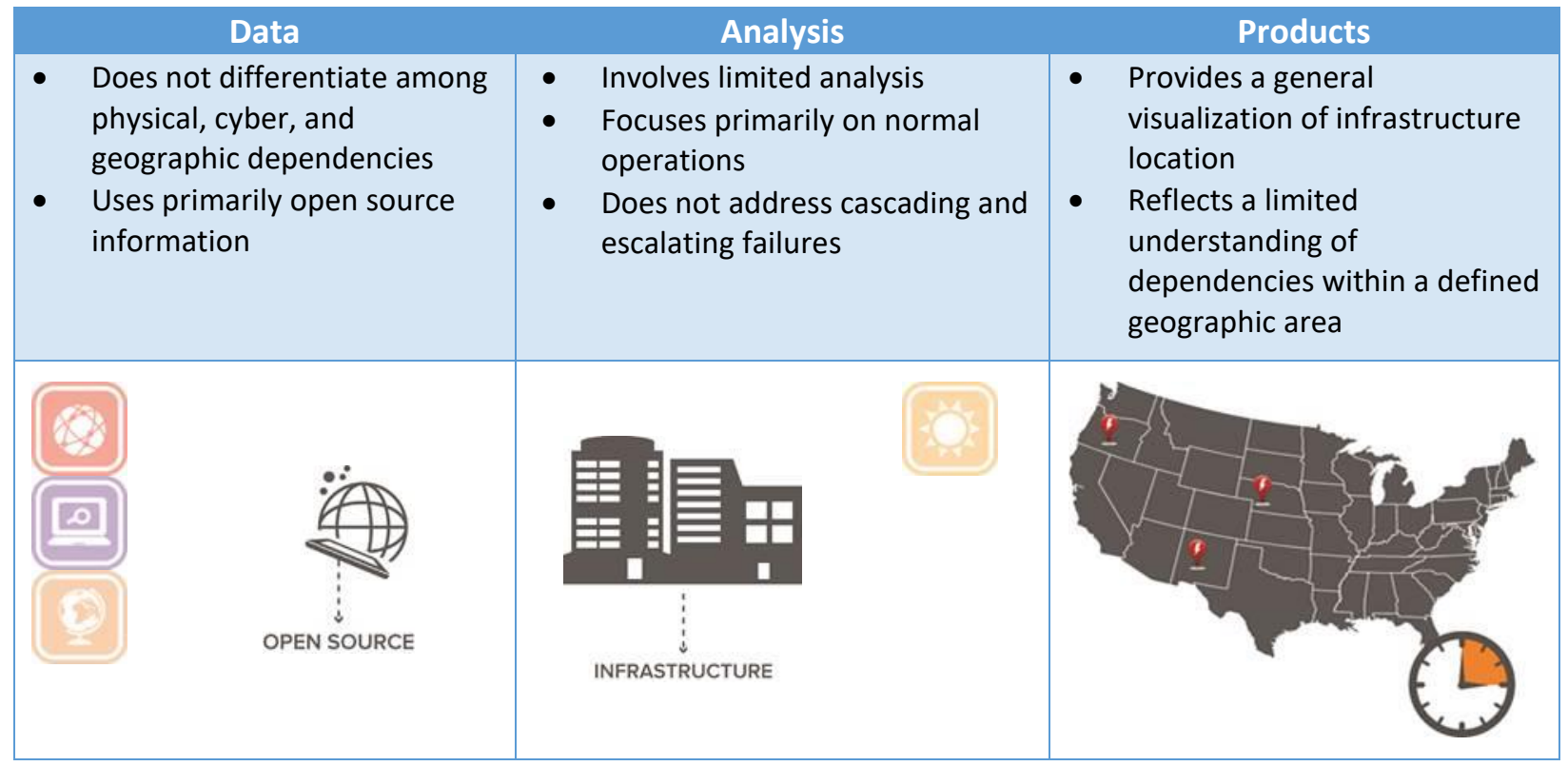

Table 3 - Characteristics of Intermediate Dependency and Interdependency Analysis

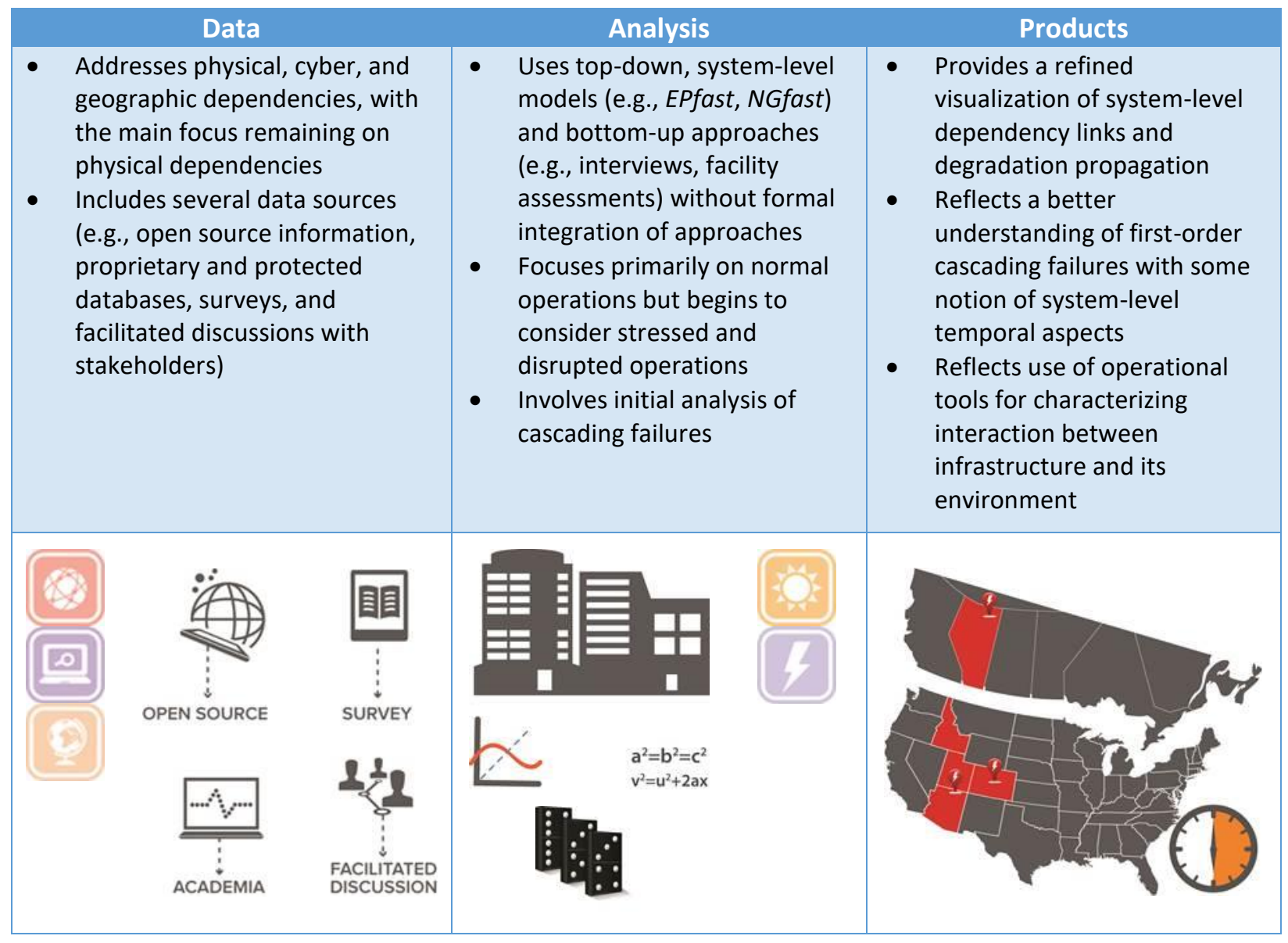




\subsection{Advanced Analysis}

Advanced Analysis considers all dimensions of critical infrastructure dependencies and interdependencies, including operating environment, coupling and response behaviors, types of failure, infrastructure characteristics, and state of operations (Petit et al. 2015). This step requires the creation of new data collection mechanisms and the integration of existing independent assessment approaches. Through this more advanced analysis, partners are able to transition from initial analysis centered on individual facilities to broader systems-level evaluations of infrastructure dependencies and interdependencies. For example, Argonne is conducting an internal research and development project to integrate the EPfast and NGfast models, which will model electric power and natural gas system interdependencies and simulate cascading failures across multiple states (Portante et al. 2016). The multi-system-level, EPfast-NGfast modeling and failure analysis is an example of an emerging top-down approach that can combine with new bottom-up approaches, such as the Dependency Survey Tool, to improve regional dependency and interdependency analysis. Table 4 presents an overview of the data, analysis, and products characterizing Advanced Analysis.

Table 4 - Characteristics of Advanced Dependency and Interdependency Analysis

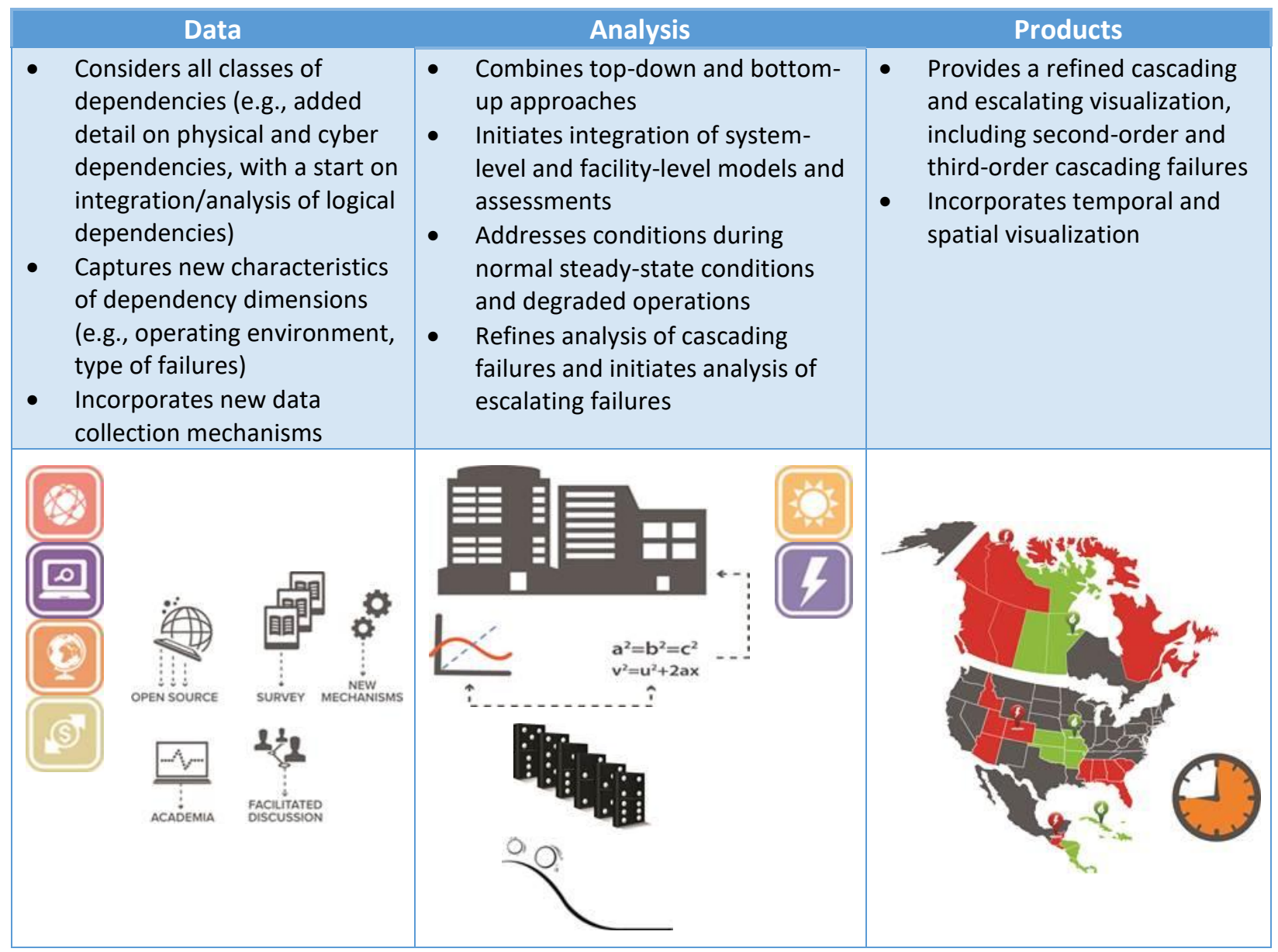




\subsection{Optimal Analysis}

Optimal Analysis produces a comprehensive understanding of all dependency and interdependency dimensions. Through these activities, decision-makers can anticipate and characterize, in real time, how all dependency and interdependency dimensions influence the protection and resilience of critical infrastructure systems. This effort requires a collaborative environment that promotes information sharing and multidisciplinary analyses and must expand the overall analysis beyond consideration of critical infrastructure only (e.g., it should consider environmental, social, and economic characteristics of a region). A combined bottom-up and top-down approach can capture global interactions among these subsystems to better understand the resilience of a region. Table 5 presents an overview of the data, analysis, and products characterizing Optimal Analysis.

Table 5 - Characteristics of Optimal Dependency and Interdependency Analysis

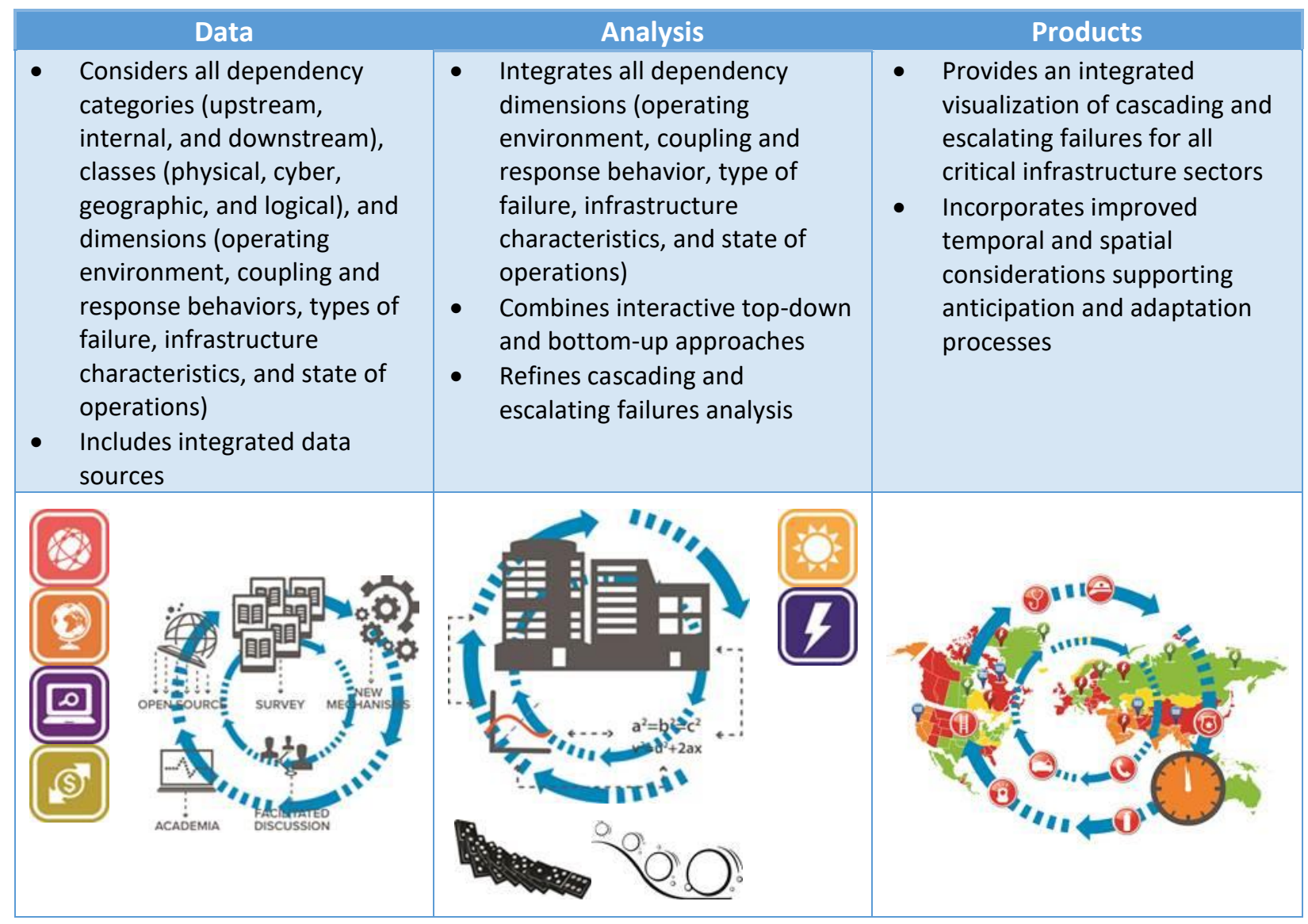




\section{SYSTEMS APPROACH to REGIONAL DEPENDENCY AND INTERDEPENDENCY ANALYSIS}

Infrastructure dependency and interdependency analysis can be analytically complicated, time consuming, and costly, which, in turn, can limit the ability of stakeholders to understand and use this information to make risk-informed decisions that enhance resilience. To manage these complexities, the infrastructure community should use a process that helps partners prioritize resilience assessment efforts through adopting a "systems approach" to performing regional dependency and interdependency analysis.

This approach is based on the assumption that a critical asset or facility can be considered as part of a broader system of infrastructure. Higher-level constructs (e.g., a community or a region) include multiple systems. As such, a community or a region operates as a "system of systems." Viewed within this framework, high-level systems analysis-using proven and scientifically sound tools-can help identify the most critical lower-level systems. This information can, in turn, help determine where to conduct more detailed site assessments on only the most critical asset-level components (Carlson et al. 2012).

A "system of systems" approach can help establish the appropriate scope of a dependency analysis, as well as the specific assets and/or subsystems for which resilience-related information should be collected (Carlson et al. 2012). Using this approach, analysis would consider the high-level context (e.g., a geographic region or an industry sector) and the associated states of these systems, ultimately represented by the most critical assets that will inform the scope and focus of a resilience assessment, including the most critical assets from which to collect dependency data.

Executing this "systems of systems" approach requires using hard and soft system methodologies and combining top-down and bottom-up data collection and analysis methods to fully consider regional infrastructure dependencies and interdependencies (Figure 3).

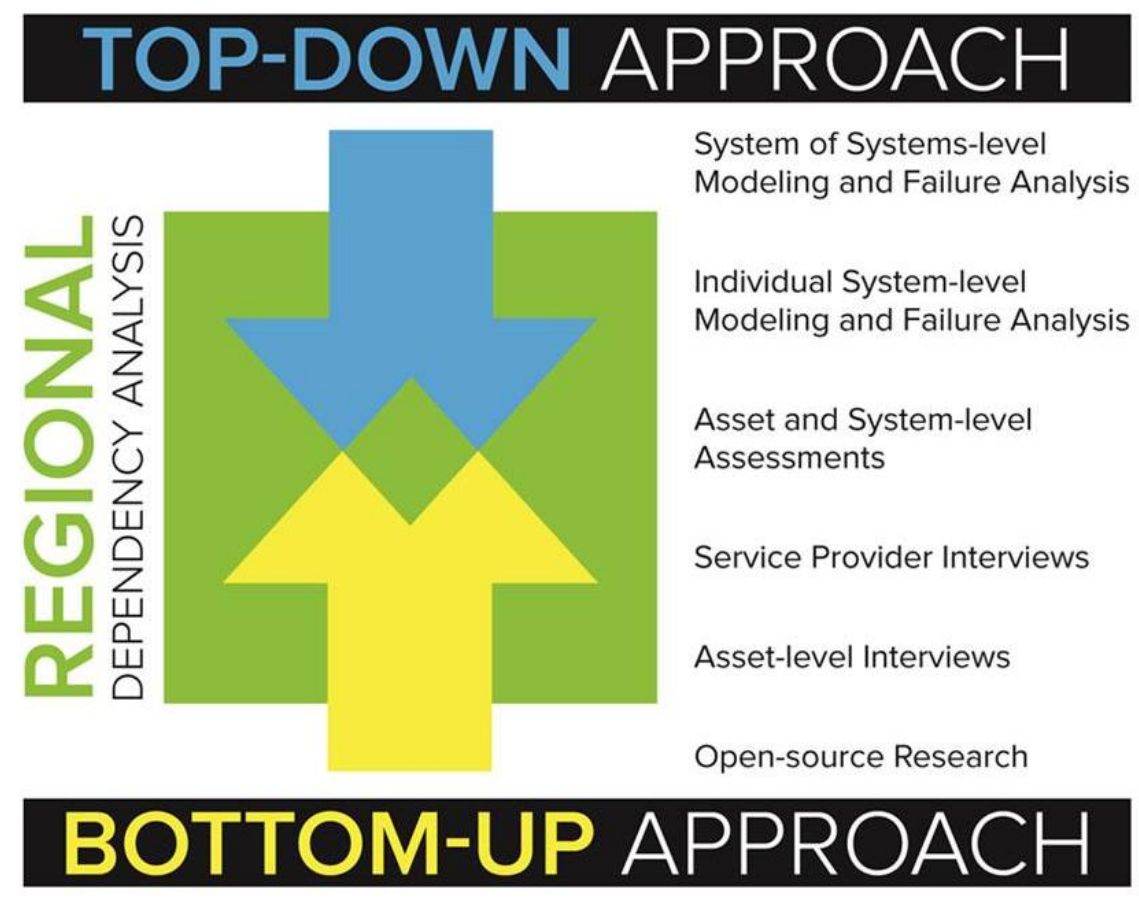

Figure 3 - Top-down and Bottom-up Approaches to Regional Dependency Analysis 
Anticipation of cascading and escalating failures requires analyzing risk and resilience capabilities across organizational boundaries (Hokstad, Utne, and Vatn 2012). It is therefore necessary to conduct assessments and cooperate both vertically, that is, within a given sector, and horizontally, or across sectors (Hokstad, Utne, and Vatn 2012).

This approach can be carried out by combining hard and soft system methodologies:

- The soft system methodology was designed for analyzing complex system problems and defining ways to "improve the systems and solve the problems identified" (Checkland 1981). This methodology is traditionally used to address human activity systems that cannot be quantified easily (Wastell 2012). The classic soft systems methodology has seven stages and captures different perspectives, including stakeholders' needs and requirements (Williams 2005).

- Hard system methodologies assume that every system can be disaggregated into a number of subsystems and are traditionally used in engineering and operations research. Hard system methodologies traditionally use simulation methods and techniques to represent an abstraction of the system and provide solutions for organizational and managerial problems (Schwaninger 2009).

Top-down and bottom-up approaches are used in several engineering fields, including reliability, safety, system, and resilience engineering (Leveson 2003; Crespi, Galstyan, and Lerman 2005). Top-down approaches involve analyzing a system (or multiple systems) in its entirety and then focusing on its component parts (Crespi, Galstyan, and Lerman 2005). Bottom-up approaches consist of analyzing the component parts of a system individually and then building on this analysis to describe the system as a whole (Crespi, Galstyan, and Lerman 2005). Taking a closer look at two of these engineering fields, reliability engineering generally uses a bottom-up approach to evaluate the effect of component failures on system function, whereas safety engineering generally requires a top-down approach that evaluates how hazardous states can occur at the system level, leading to failures of individual components (Leveson 2003). These failure and hazard analysis techniques are applicable to analysis of all types of systems and subsystems or to an integrated set of systems (Ericson 2015) and can be used for a number of purposes, including:

- Aiding in system design to withstand failure,

- Assisting in operational planning, and

- Providing inputs to risk management (FAA 2000).

Given the dynamic and uncertain nature of threats, there is a critical need for an integrated approach to optimize resilience and protection of critical infrastructure. A top-down approach provides simultaneous analysis of an entire system, enabling decision-makers to define resilience measures for implementation at the system level. A bottom-up approach is more appropriate to determine resilience procedures at the facility level (Gopalakrisshnan and Peeta 2010). Combining top-down and bottom-up approaches is a comprehensive method that can be used to support decision-making based on accepted engineering principles (Linkov et al. 2014; Hollnagel 2014; Leveson 2011).

Dependencies and interdependencies exist at individual levels (e.g., assets are interconnected with other assets) and between levels (e.g., assets are interconnected with systems, systems with other systems, and so on). ${ }^{4}$ Table 6 presents attributes of bottom-up and top-down approaches to critical infrastructure dependencies and interdependencies assessments.

4 DHS created the Infrastructure Data Taxonomy (IDT) to facilitate a common understanding of infrastructure terminology within the critical infrastructure protection community. The IDT organizes critical infrastructure in different levels (i.e., sector, subsector, segment, subsegment, and asset) where each component within a level is 
Regional Resiliency Assessment Program Dependency Analysis Framework

Table 6 - Comparison of Bottom-up and Top-down Approaches

\begin{tabular}{|c|c|}
\hline Bottom-Up Approach & Top-Down Approach \\
\hline Decentralized & Centralized \\
\hline Targets data collection at asset level & Targets data collection at system level \\
\hline Based on actual operations and conditions & Often based on models and large datasets \\
\hline Identifies facility-level interdependencies & Identifies system-level interdependencies \\
\hline Moves from the specific to the global & Moves from the global to the specific \\
\hline
\end{tabular}

\section{EXAMPLE DEPENDENCY AND INTERDEPENDENCY ANALYSES FROM RECENT RRAP PROJeCTS}

The goal of the RRAP is to generate greater understanding and action among public and private sector partners to improve the resilience of a region's critical infrastructure. Key objectives of RRAP projects include:

- Resolving infrastructure security and resilience knowledge gaps;

- Informing risk management decisions;

- Identifying resilience-building opportunities and strategies; and

- Improving critical partnerships among stakeholders.

Critical infrastructure dependencies and interdependencies are important focus areas for many RRAP projects. Through these collaborative projects, DHS helps stakeholders develop detailed knowledge about critical operational and spatial relationships among important infrastructure systems. The analysis conducted through RRAP projects yields practical outputs for stakeholders, including maps and diagrams that describe important relationships across regional infrastructure; detailed examinations of specific dependencies among assets and systems; and evaluations of the strengths of dependencies and operational alternatives. Together, stakeholders can use these outputs to drive specific actions that improve resilience over a multiyear period, including by expanding knowledge about regional infrastructure and key failure points; improving facility risk management and regional response and recovery planning; and expanding the universe of partners collaborating on infrastructure resilience initiatives.

RRAP projects have explored infrastructure dependencies and interdependencies through a combination of top-down and bottom-up approaches. RRAP activities have included providing broader contextual analyses to understand the likelihood of specific threats and hazards and potential infrastructure failure considerations, as well as tailored interdependency analyses using system-level modeling and assetbased assessments to define potential cascading failures. Table 7 presents the objectives, main stakeholders, and relevant infrastructure systems considered as part of five recent RRAP projects. (Appendix A provides more detailed information on the models used to support this analysis; a description of the dependency analysis process; and data inputs used in the Maine, Florida Fuels, and Ashburn RRAP projects, among others.) The sections that follow provide specific examples of results from these projects that illustrate approaches for analyzing infrastructure dependencies and interdependencies, including a blending of top-down and bottom-up approaches.

defined by a distinct description. For example, a wastewater lift/pump station $\mathrm{X}$ (facility $\mathrm{X}$ ) is categorized in the Water Sector, Wastewater Facility Sub-Sector, Wastewater Collection System Segment, and Lift/Pump Station Sub-Segment. Furthermore, facility $\mathrm{X}$ requires that operational and technical elements (assets) be functional. 
Regional Resiliency Assessment Program Dependency Analysis Framework

Table 7 - Overall Objectives, Stakeholders, and Infrastructure Systems Addressed in Recent RRAPs

\begin{tabular}{|c|c|c|c|}
\hline $\begin{array}{l}\text { RRAP } \\
\text { Project }\end{array}$ & Objective & Main Stakeholders & $\begin{array}{c}\text { Infrastructure } \\
\text { Systems }\end{array}$ \\
\hline Maine & $\begin{array}{l}\text { Examine coastal lifeline sectors in } \\
\text { the context of impacts attributable } \\
\text { to climate change and develop } \\
\text { products to inform adaptation } \\
\text { planning. }\end{array}$ & $\begin{array}{l}\text { Maine Department of } \\
\text { Transportation (MDOT), } \\
\text { Maine Geological Survey } \\
\text { (MGS), and City of Portland }\end{array}$ & $\begin{array}{l}\text { Electric Power, Petroleum, } \\
\text { Transportation, Water } \\
\text { and Wastewater, } \\
\text { Communications }\end{array}$ \\
\hline $\begin{array}{l}\text { Florida } \\
\text { Fuels }\end{array}$ & $\begin{array}{l}\text { Analyze Florida's transportation } \\
\text { system and the critical infrastructure } \\
\text { assets it supports that are integral to } \\
\text { the delivery of petroleum fuels. } \\
\text { Analyze the resilience of port } \\
\text { operations and the SCADA systems } \\
\text { that support petroleum fuels } \\
\text { deliveries. }\end{array}$ & $\begin{array}{l}\text { Florida Division of } \\
\text { Emergency Management } \\
\text { (FDEM) and Florida } \\
\text { Department of Law } \\
\text { Enforcement (FDLE) }\end{array}$ & $\begin{array}{l}\text { Petroleum, } \\
\text { Transportation, Electric } \\
\text { Power, Water and } \\
\text { Wastewater, } \\
\text { Communications }\end{array}$ \\
\hline Cajon Pass & $\begin{array}{l}\text { Examine the surface transportation } \\
\text { artery via the San Bernardino } \\
\text { mountains to Las Vegas and } \\
\text { eastward. }\end{array}$ & $\begin{array}{l}\text { California Office of } \\
\text { Emergency Services } \\
\text { (CalOES) }\end{array}$ & $\begin{array}{l}\text { Transportation, Electric } \\
\text { Power, Water and } \\
\text { Wastewater, } \\
\text { Communications }\end{array}$ \\
\hline Ashburn & $\begin{array}{l}\text { Provide actionable analysis on the } \\
\text { dependencies and } \\
\text { interdependencies of lifeline } \\
\text { infrastructure supporting the } \\
\text { operations of the Ashburn-area data } \\
\text { centers. }\end{array}$ & $\begin{array}{l}\text { Virginia Department of } \\
\text { Emergency Management } \\
\text { (VDEM) and Virginia } \\
\text { Homeland Security Advisor }\end{array}$ & $\begin{array}{l}\text { Information Technology, } \\
\text { Communications, Electric } \\
\text { Power, Water }\end{array}$ \\
\hline Charleston & $\begin{array}{l}\text { Provide State and local stakeholders } \\
\text { with actionable analysis regarding } \\
\text { emergency and business continuity } \\
\text { planning gaps, critical infrastructure } \\
\text { dependencies and } \\
\text { interdependencies, and risk } \\
\text { mitigation measures to strengthen } \\
\text { the region's transportation sector } \\
\text { resilience. }\end{array}$ & $\begin{array}{l}\text { South Carolina Ports } \\
\text { Authority (SCPA) and } \\
\text { South Carolina State Law } \\
\text { Enforcement Division } \\
\text { (SLED) }\end{array}$ & $\begin{array}{l}\text { Transportation, Electric } \\
\text { Power, Water and } \\
\text { Wastewater, } \\
\text { Communications }\end{array}$ \\
\hline
\end{tabular}

\subsection{Maine RRAP}

The State of Maine is experiencing shifts in atmospheric and oceanographic conditions that put it at the precipice of abrupt climate change. The Maine RRAP focuses on the local and regional consequences of climate disruptions and their impacts on critical infrastructure in the Casco Bay Region, the most developed and populous region in Maine. As part of this process, the project team conducted a detailed hazard analysis - which involved developing climate projections for the Casco Bay Region based on global climate models, which are dynamically downscaled using a regional climate model. The team then used those results to prioritize and inform related dependency analyses on specific infrastructure systems. For example, the team performed an assessment of the vulnerability of key substations to characterize the resilience of the regional electrical power system to potential future flooding and storm impacts under climate change. This substation case study considered historical and projected changes in average and extreme precipitation, sea-level rise, and storm surge that were then used to define two disruption scenarios. 
The failure analysis-predominantly a top-down analysis approach-defined how the disruption scenarios would affect the built environment and lead to the failure of critical infrastructure assets. For the Maine RRAP, the failure analysis used proprietary data sources for locating the infrastructure constituting the electric grid, and fragility curves for defining how electric power infrastructure would be affected by the natural hazard scenarios.

Considering the two scenarios defined during the hazard analysis, the RRAP team projected that six substations would be affected by flooding resulting from a combination of sea-level rise and heavy precipitation. Static mapping products can illustrate high-consequence failure points and potential cascading failures derived from hazard and infrastructure models; however, interactive tools that allow a user to explore the impact(s) of a hazard on the built environment dynamically are often the most impactful means of communicating the outputs of these complex analyses. Figure 4 shows possible effects of the power outage resulting from the RRAP case study analysis.

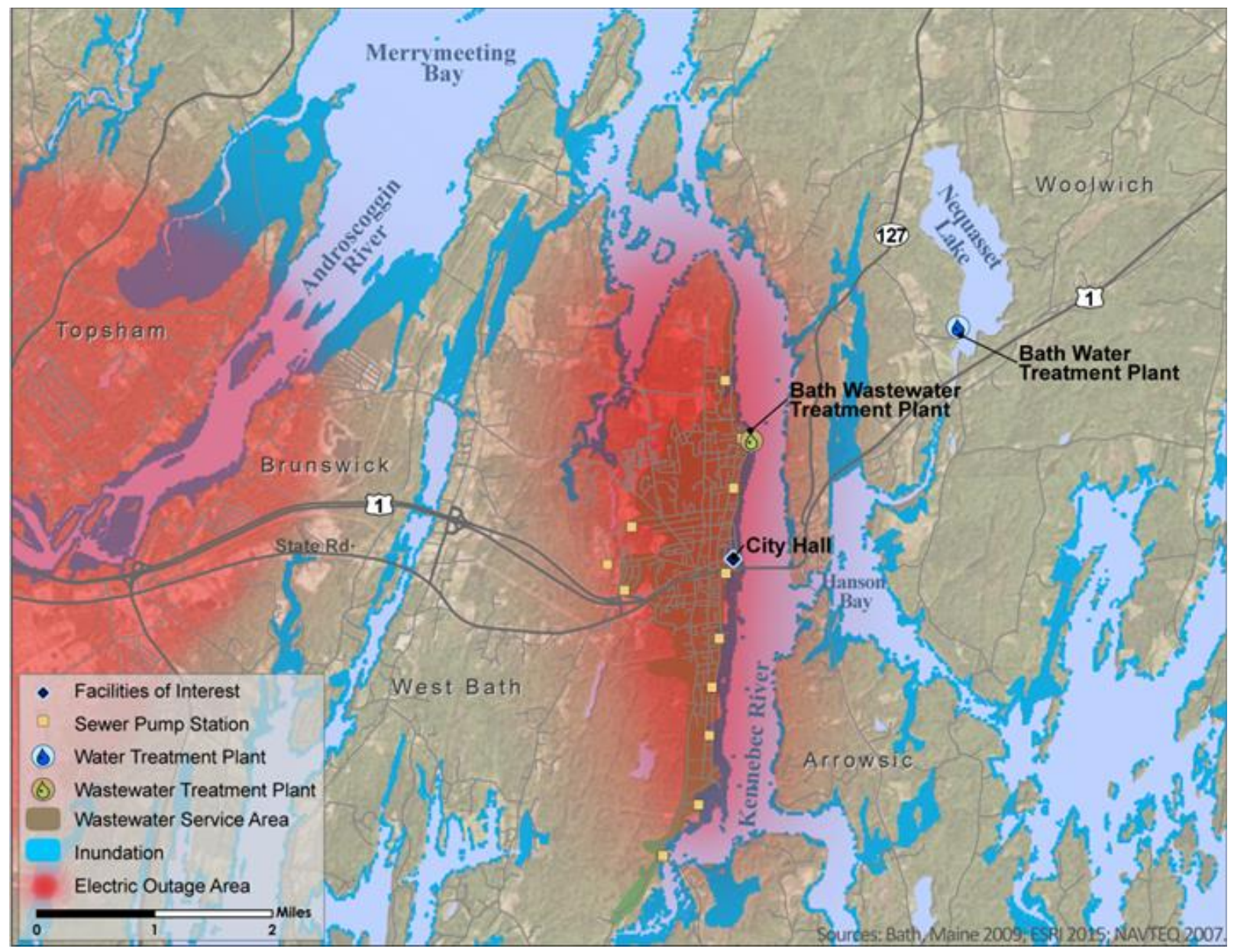

Figure 4 - Possible Effects of the Power Outage Case Study 


\subsection{Florida Fuels RRAP}

No significant oil production facilities or refineries exist in Florida, so all petroleum products must be transported into the State. The primary goal of the Florida Fuels RRAP was to provide Florida agencies with actionable analysis to help them improve their understanding of the complex petroleum fuel supply chain serving the State, which would help them identify overall vulnerabilities and thus inform efforts that address Florida's fuel transportation system vulnerabilities. In addition, the project also helped State and local planners identify overall vulnerabilities throughout the petroleum fuel supply chain and develop a realistic strategy designed to mitigate and manage a large-scale failure of petroleum-related port operations.

Figure 5 presents case study results from the Florida Fuels RRAP that illustrate the propagating disruptions between the natural gas and electric power infrastructure systems in Florida modeled with EPfast and NGfast. In this example, analysts were able to combine two tools used in dependency analyses to model interdependencies between systems (i.e., a "system of systems").

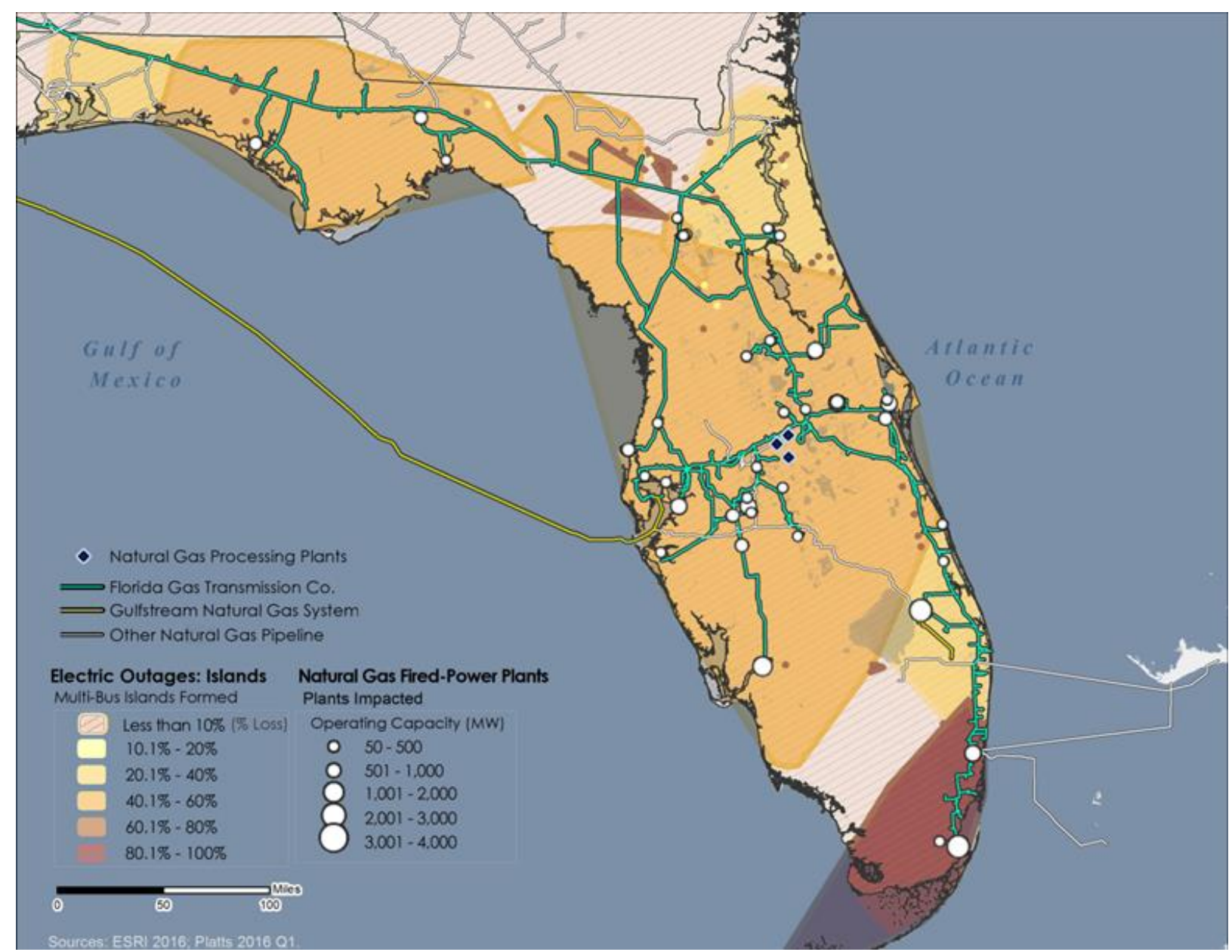

Figure 5 - Example of "System of Systems" Modeling and Failure Analysis (Source: Portante et al. 2016) 
The scenario postulates the occurrence of a complete break on a major interstate transmission pipeline supplying natural gas to the State, which results in a 100 percent reduction in the flow of gas through the pipeline. The pipeline break also disrupts fuel delivery to a large number of gas-fired power plants in the State. ${ }^{5}$ Electric power generation would be affected, leading to statewide potential disruptions with varying load loss intensity ranging from 10 to 100 percent (Portante et al. 2016).

\subsection{Cajon Pass RRAP}

The Cajon Pass is a vital corridor between Southern California and the rest of the Nation. Energy, communications, and transportation infrastructure (i.e., road and rail lines carrying goods to and from the Ports of Los Angeles and Long Beach) cross the Pass. The Cajon Pass RRAP assessed impacts on these essential systems after postulating the occurrence of a major earthquake at the southern San Andreas Fault. As part of this project, DHS conducted detailed analyses of (1) the transportation-related economic impacts anticipated from a Cajon Pass closure, and (2) consequences of earthquake-induced power outages, as well as outcomes of different restoration strategies for Cajon Pass electric assets.

System-level modeling is useful in characterizing both the activities and time needed to restore a critical infrastructure system after degradation. The Cajon Pass RRAP project used the Restore $\bigcirc$ model, a stand-alone program that runs Monte Carlo simulations using transition diagrams to model infrastructure repair processes. Restore (C estimates the restoration time(s) for a selected infrastructure asset or system while accounting for uncertainty (e.g., dependencies on lifeline infrastructure sectors). Based on the identified restoration steps, the model defines the time distribution for completing the system restoration. In the Cajon Pass RRAP, analysts used Restore $C$ to determine reasonable restoration times for earthquake-damaged rail and road infrastructure within the Pass.

Figure 6 shows example output from the Restore $\subset$ model using a transition diagram that considers transportation and telecommunications dependencies within the steps required to repair a ruptured natural gas pipeline.

5 An additional natural gas pipeline is scheduled to be operational by mid-year in 2017, which will mitigate the effects identified during this RRAP. 


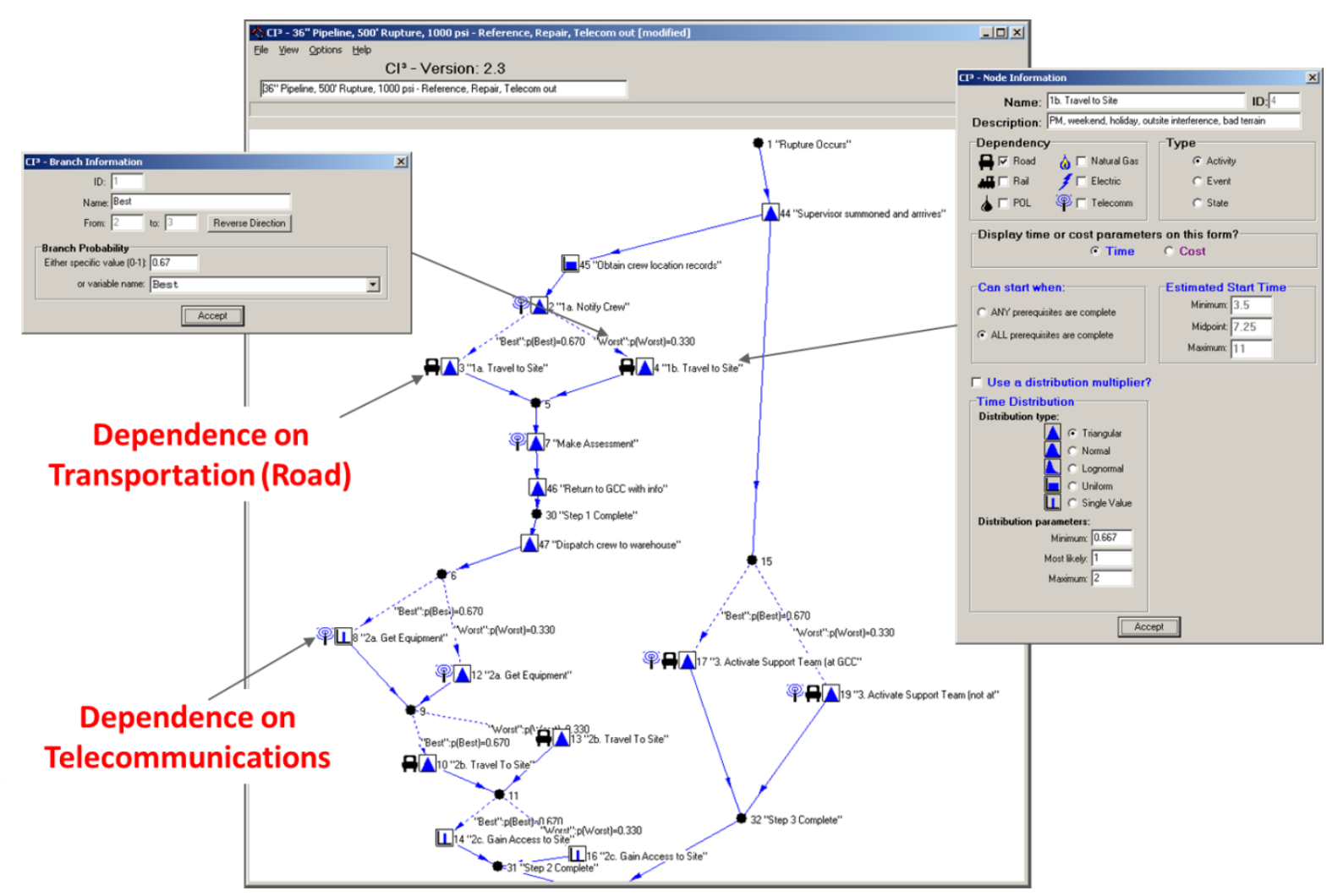

Figure 6 - Repair and Restoration of a Ruptured Natural Gas Pipeline

\subsection{Port of Charleston RRAP}

The Port of Charleston RRAP project assessed the vulnerabilities of port terminals and regional surface transportation networks with a focus on the critical dependencies among assets, systems, and operations that facilitate the port's intermodal capabilities and the region's freight mobility capacities. Operations at all five port terminals depend on services and resources from supporting regional lifeline infrastructure. In order to operate at full capacity, dependencies on electric power, fuels, transportation routes, communications, information technology (IT), water, and wastewater must be satisfied. Degradation of one or a combination of these service and resource supplies would have a detrimental effect on the port operations.

As part of this RRAP, analysts collected dependency data-considered a bottom-up approach or analysis effort-from South Carolina Port Authority terminals (Figure 7). 


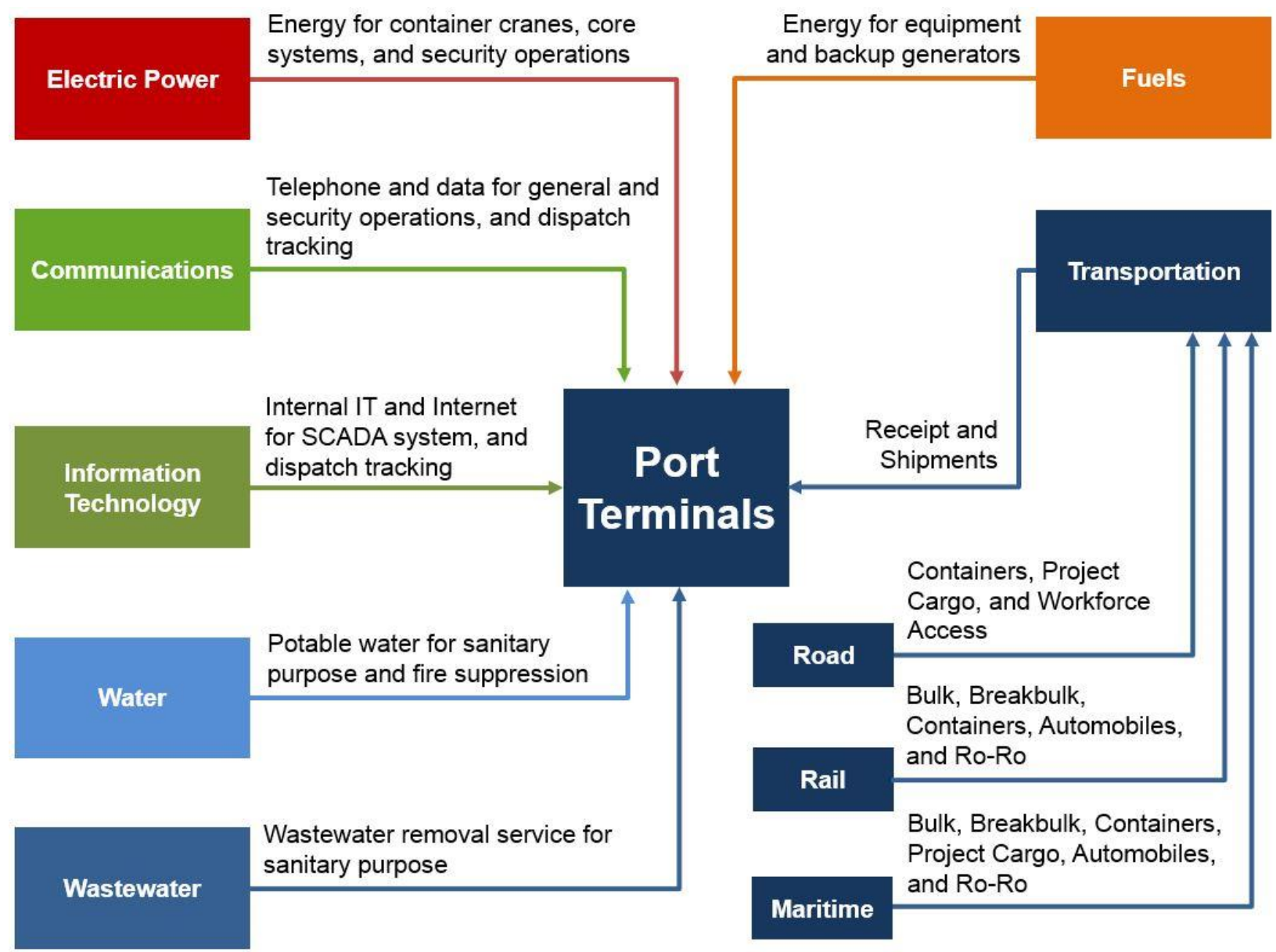

Figure 7 - Overview of Upstream Dependencies for Port Terminals ${ }^{6}$

This information allowed analysts to generate dependency curves for all first-order upstream dependencies at port terminals, showing how the failure of critical infrastructure systems would affect a specific facility over time. Figure 8 presents how facility-level information can be integrated in a dependency curve, which represents the impact of the loss of a given resource over time.

6 Ro-Ro-Roll On, Roll Off. 


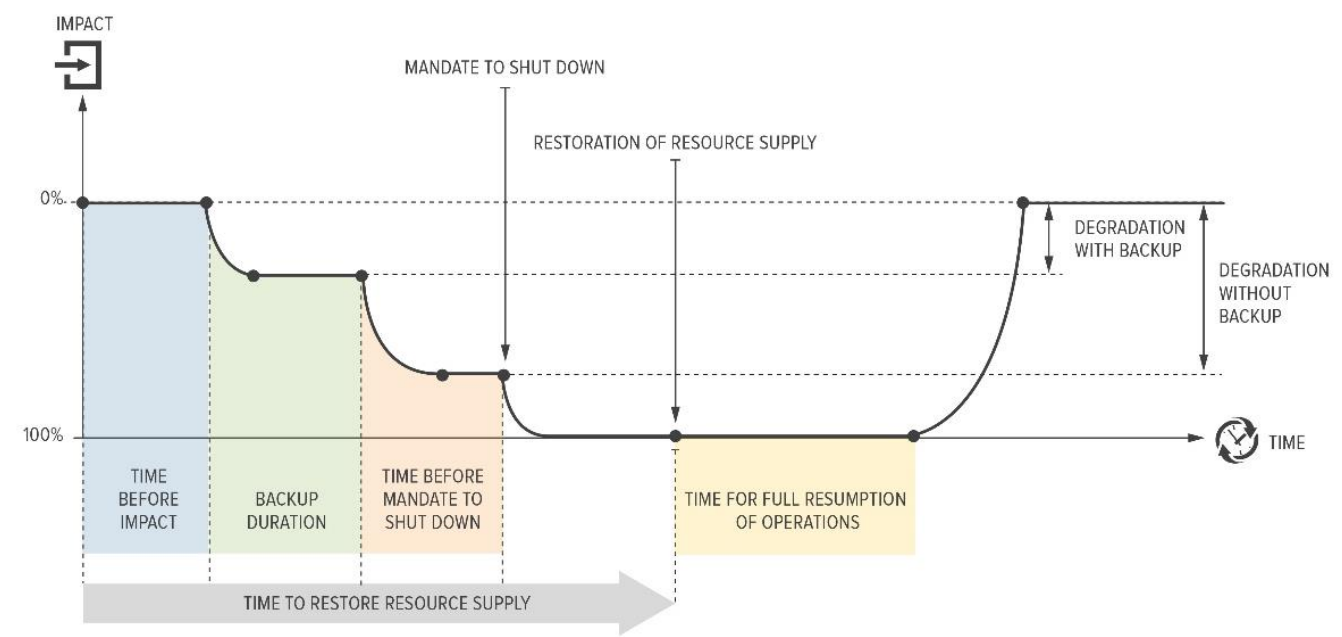

Figure 8 - Example of Facility Dependency Curve (Source: Petit, Wallace, and Phillips 2014)

\subsection{Ashburn RRAP}

The Ashburn RRAP focused on the resilience of the Internet backbone infrastructure located in the Ashburn area of Northern Virginia. The cluster of data centers in this region is an important interconnection point for global Internet traffic given the presence of major Interexchange points. With its unique concentration of both fiber and power, on average, 50 to 70 percent of all worldwide Internet traffic flows through the greater Ashburn-area data centers. The infrastructure examined in this project included individual fiber routes and installations; data centers; communications providers; and the power, water, and emergency services sectors that support Internet infrastructure (Figure 9).

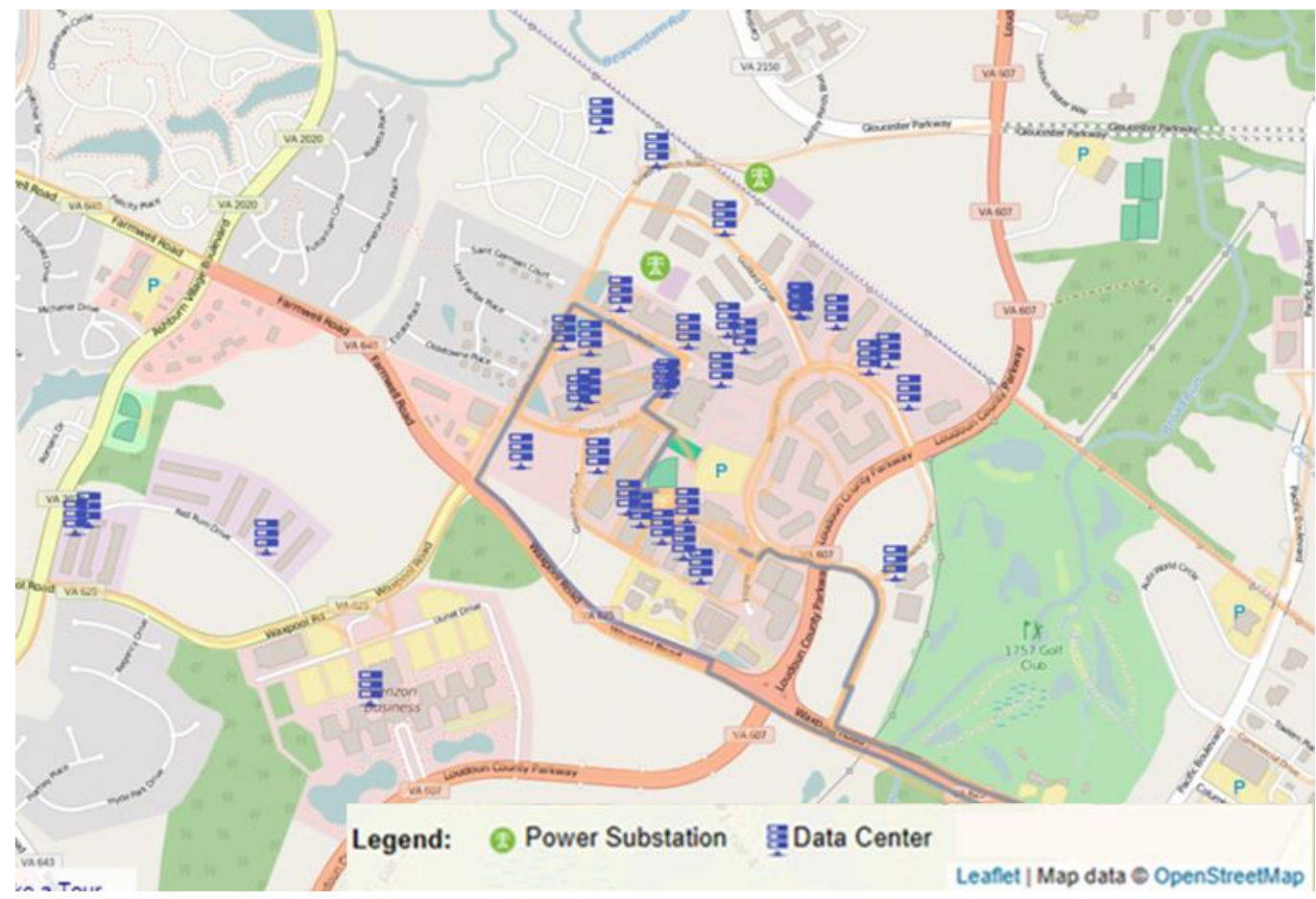

Figure 9 - Cluster of Data Centers in Loudoun County 
Among the outputs created through this RRAP was a dynamic, geographic information system (GIS) product that visualizes infrastructure dependencies both spatially and temporally, allowing analysts to test different scenarios to evaluate the extent of potential consequences generated by potential dysfunction occurring within utility systems.

In the case of Ashburn, transportation infrastructure and private trucking companies are necessary to supply diesel fuel to data center facilities in the event of an extended electric interruption. The tool that the team developed provides an option that shows the outage area generated by the disruption of electric power substations and identifies what data centers would be affected. Predicted outage area is based on an EPfast scenario that assumes summer peak-day load conditions that are derived from proprietary electric infrastructure information.

There are more than $\mathbf{2 0}$ data centers clustered around the Beaumeade Circle area in Ashburn (Figure 10).

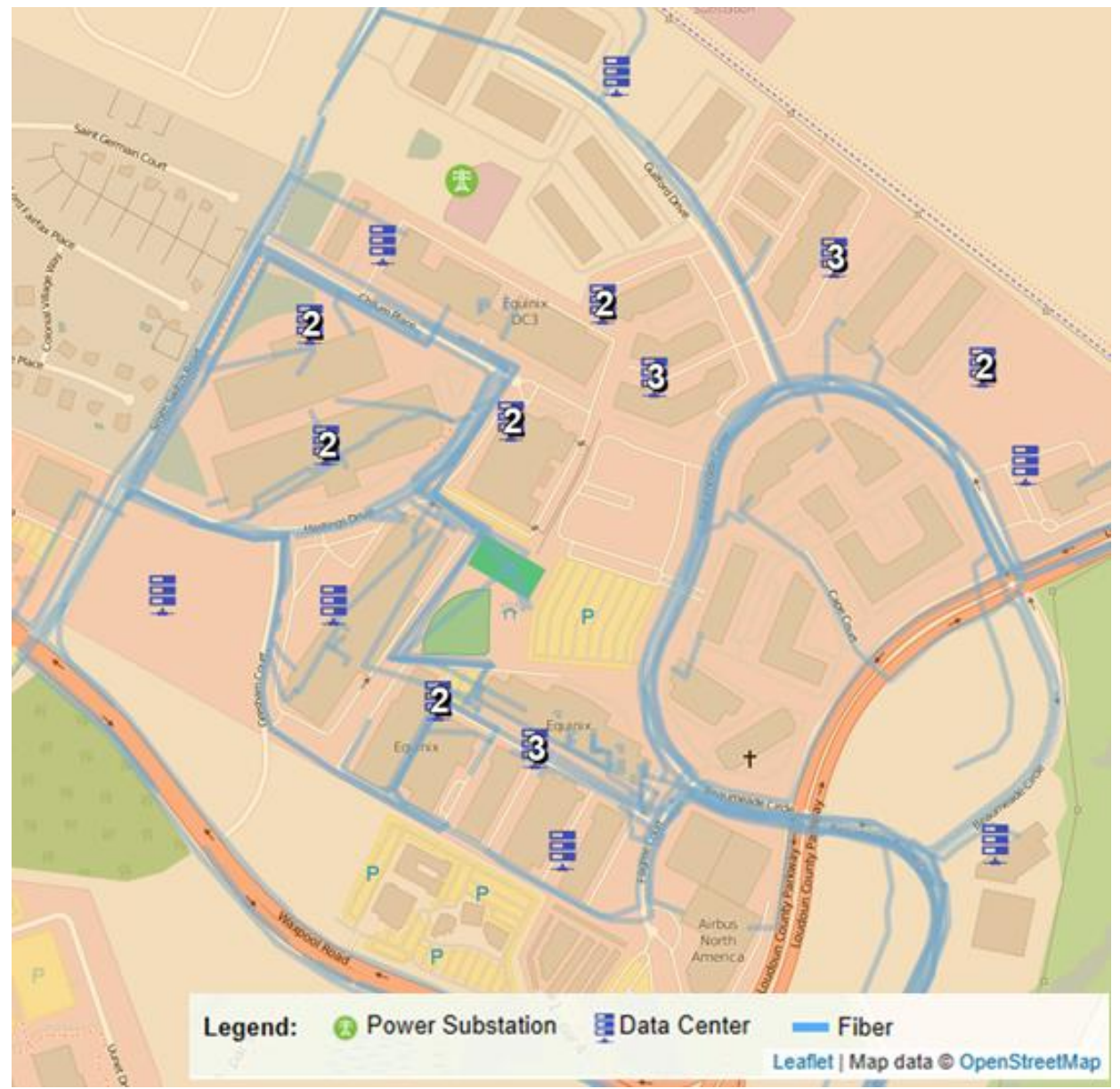

Figure 10 - Beaumeade Circle Data Center Cluster ${ }^{7}$

Data centers in the Beaumeade Circle area collectively would require deliveries from three to seven fuel trucks per hour to run at full capacity if they were operating entirely on electric power from their onsite

7 All data center information in this map was gathered from publicly available sources. Information should not be considered complete. The data are "best-effort accurate" as of fall 2015. 
generators. During an electric power outage, other infrastructure assets in the area would also require fuel to operate their backup generators, which would result both in logistical difficulties in delivering the fuel and in supply constraints.

\section{SUMmary AND NEXT STEPS}

The common understanding and consistent analytic approach for critical infrastructure dependencies and interdependencies outlined here prioritizes the need to tie together top-down and bottom-up approaches in order to produce a comprehensive "system of systems" understanding that can inform PSCD programs, including but not limited to the RRAP. In particular, this approach provides a conceptual foundation for conducting dependency-focused RRAPs, as well as hazard-driven RRAPs that account for the effects of specific natural and human-caused hazards on interdependent infrastructure systems.

Looking ahead, PSCD can advance efforts to institutionalize this framework for analyzing critical infrastructure dependencies and interdependencies by pursuing the following activities of:

- Convening a joint workshop with PSCD headquarters and field personnel, Infrastructure Information Collection Division (IICD), and national laboratory stakeholders to identify nearterm opportunities that leverage both the bottom-up Dependency Survey Tool and top-down multisystem modeling and failure analysis capabilities in emerging RRAP projects.

- Updating existing training on dependencies and interdependencies (e.g., one-day dependency training delivered to analysts within the Office of Cyber and Infrastructure Analysis) to reflect this framework and deliver the training to RRAP teams and stakeholders to ensure common understanding of key concepts.

- Defining a common analytical framework for all types of RRAPs-including characterization projects, dependency projects, and hazard-driven projects - that expands on the building blocks of data, analysis, and products used in this approach and provides a shared roadmap for RRAP projects that explore different infrastructure systems across the Nation. 


\section{REFERENCES}

Carlson, L., G. Basset, W. Buehring, M. Collins, S. Folga, B. Haffenden, F. Petit, J. Phillips, D. Verner, and R. Whitfield, 2012, Resilience: Theory and Applications, Argonne National Laboratory, Decision and Information Sciences Division, ANL/DIS-12-1, Argonne, III., USA, available at http://www.ipd.anl.gov/anlpubs/2012/02/72218.pdf, accessed July 14, 2017.

Checkland, P.B., 1981, Systems Thinking, Systems Practice, Chichester: John Wiley.

Clifford, M., 2015, "National Call to Action: The Resilient Infrastructure Initiative," The CIP Report, Center for Infrastructure Protection and Homeland Security, George Mason University School of Law, Washington, D.C., USA, December, available at http://cip.gmu.edu/2015/12/02/national-call-to-actionthe-resilient-infrastructure-initiative/, accessed July 14, 2017.

Crespi, V., A. Galstyan, and K. Lerman, 2005, "Comparative Analysis of Top-Down and Bottom-up Methodologies for Multi-Agent System Design," AAMAS'05, July 25-29, Utrecht, Netherlands, available at http://www.isi.edu/ galstyan/papers/crespi.pdf, accessed July 14, 2017.

DHS (U.S. Department of Homeland Security), 2016, Written Testimony of NPPD Office of Infrastructure Protection Assistant Secretary Caitlin Durkovich and NPPD Office of Cybersecurity and Communications Assistant Secretary Andy Ozment for a House Committee on Homeland Security, Subcommittee on Cybersecurity, Infrastructure Protection, and Security Technologies hearing titled "Value of DHS' Vulnerability Assessments in Protecting our Nation's Critical Infrastructure," released July 12, available at https://www.dhs.gov/news/2016/07/12/written-testimony-nppd-house-homeland-securitysubcommittee-cybersecurity, accessed July 14, 2017.

Ericson, A.E., 2015, Hazard Analysis Techniques for System Safety: Edition 2, New York: John Wiley \& Sons.

FAA (Federal Aviation Administration), 2000, "Chapter 9: Analysis Techniques," FAA System Safety Handbook, December 30, available at https://www.faa.gov/regulations policies/ handbooks manuals/aviation/risk management/ss handbook/media/Chap9 1200.pdf, accessed July 14, 2017.

Gopalakrisshnan, K., and S. Peeta, 2010, Sustainable and Resilient Critical Infrastructure Systems Simulation - Modeling, and Intelligent Engineering, New York: Springer, 265 p.

Hokstad, P., I.B. Utne, and J. Vatn, 2012, Risk and Interdependencies in Critical Infrastructures -A Guideline for Analysis, New York: Springer, 252 p.

Hollnagel, E., 2014, Safety-I and Safety-II - The Past and Future of Safety Management, New York: Ashgate Publishing Limited, $187 \mathrm{p}$.

Leveson, N., 2003, White Paper on Approaches to Safety Engineering, available at http://sunnyday.mit.edu/caib/concepts.pdf, accessed July 14, 2017.

Leveson, N.G., 2011, Engineering a Safer World - Systems Thinking Applied to Safety, Engineering Systems, Cambridge, Massachusetts: The MIT Press, available at https://mitpress.mit.edu/sites/default/files/titles/free download/9780262016629 Engineering a Safer World.pdf, accessed July 14, 2017. 
Linkov, I., E. Anklam, Z.A. Collier, D. DiMase, and O. Renn, 2014, "Risk-based Standards: Integrating Topdown and Bottom-up Approaches," Environment Systems and Decisions, March, Volume 34, Issue 1, pp. 134-137, available at http://link.springer.com/article/10.1007/s10669-014-9488-3, accessed July 14, 2017.

Petit, F., D. Verner, D. Brannegan, W. Buehring, D. Dickinson, K. Guziel, R. Haffenden, J. Phillips, and J. Peerenboom, 2015, Analysis of Critical Infrastructure Dependencies and Interdependencies, available at http://www.osti.gov/scitech/biblio/1184636, accessed July 14, 2017.

Petit, F., K. Wallace, and J. Phillips, 2014, "Interactive Dependencies Curves for Resilience Management," Journal of Business Continuity \& Emergency Planning, Vol. 8, No. 2, London, United Kingdom: Henry Stewart Publications.

Portante, E., B. Craig, J. Kavicky, L. Talaber, and S. Folga, 2016, "Modeling Electric Power and Natural Gas Systems Interdependencies," The CIP Report, Center for Infrastructure Protection and Homeland Security, George Mason University School of Law, Washington, D.C., USA, May-June, available at http://cip.gmu.edu/2016/06/03/modeling-electric-power-natural-gas-systems-interdependencies/, accessed July 14, 2017.

Rinaldi, S.M., J.P Peerenboom, and T.K. Kelly, 2001, "Identifying, Understanding, and Analyzing Critical Infrastructure Interdependencies," IEEE Control Systems Magazine, Vol. 21, No. 6, pp. 11-25, available at http://user.it.uu.se/ bc/Art.pdf, accessed July 14, 2017.

Schwaninger, M., 2009, "System Dynamics in the Evolution of the Systems Approach," Encyclopedia for Complexity and Systems Science, Vol. 9, New York, available at http://link.springer.com/referenceworkentry/10.1007/978-1-4419-7701-4 41, accessed July 14, 2017.

Wastell, D., 2012, Systems Thinking: An Introductory Essay, available at http://www.managingbydesign.net/my library/systems thinking.pdf, accessed July 14, 2017.

Williams, B., 2005, Soft Systems Methodology, The Kellogg Foundation, available at http://www.bobwilliams.co.nz/Systems Resources files/ssm.pdf, accessed July 14, 2017. 
Regional Resiliency Assessment Program Dependency Analysis Framework

\section{APPENDIX A: RRAP PROJECT EXAMPLES}

Tables A-1 through A-5 present a list of the models, along with a description of the dependency analysis process and data, used for three Regional Resiliency Assessment Programs (RRAPs): Maine, Florida Fuels, and Ashburn. 
Table A-1 - Maine, Florida Fuels, and Ashburn RRAP Objectives and Dependencies Assessments

\begin{tabular}{|c|c|c|}
\hline RRAP & Objective & General Description of Dependencies Assessment \\
\hline Maine & $\begin{array}{l}\text { Coastal lifeline sectors were examined in the } \\
\text { context of what impacts they are likely to } \\
\text { experience as a result of climate change. }\end{array}$ & $\begin{array}{l}\text { The dependency analysis in the Maine RRAP consisted of two components: a high-level } \\
\text { regional analysis, and a focused case study of electrical infrastructure dependencies in } \\
\text { the vicinity of Bath, Maine. } \\
\text { High-Level Regional Analysis: Analysis of energy supply-consumption balance and } \\
\text { dependent systems (e.g., natural gas consumption for power generation). } \\
\text { Focused Bath Case Study: (1) Geospatial analysis of storm-surge inundation of coastal } \\
\text { substations (data: EIS, }{ }^{a} \text { HSIP, ORNL Storm Surge; models: SLOSH); (2) followed by an } \\
\text { analysis of potential cascading grid failure and outage area (data: EIA, HSIP; models: } \\
\text { EPfast); (3) followed by a geospatial analysis of critical infrastructure falling within the } \\
\text { outage areas (data: open source water/wastewater, HSIP; models: ESRI ArcGIS. } \\
\text { Products: GIS mapping of outage area and dependent critical infrastructure; analysis of } \\
\text { restoration and recovery capabilities of affected infrastructure. }\end{array}$ \\
\hline $\begin{array}{c}\text { Florida } \\
\text { Fuels }\end{array}$ & $\begin{array}{l}\text { Florida's transportation system was analyzed, as } \\
\text { well as the critical infrastructure it supports that } \\
\text { is integral to the delivery of petroleum fuels. } \\
\text { The resilience of port operations and the SCADA } \\
\text { systems that support petroleum fuel deliveries } \\
\text { were also analyzed. }\end{array}$ & $\begin{array}{l}\text { The dependency analysis in the Florida Fuels RRAP consisted of two components: a } \\
\text { high-level regional analysis of fuel distribution/transportation, and a focused case study } \\
\text { of site accessibility and alternate fuel transportation options/needs at Port Canaveral. } \\
\text { High-Level Regional Analysis: Analysis of fuel terminal service area that implemented a } \\
\text { gravity-based retail coverage area model to link likely supply terminals with county- } \\
\text { level demand/consumption areas. Scenarios were then introduced to determine how } \\
\text { these service areas would shift if a supply terminal were disrupted, and then the } \\
\text { roadways into these shifting supply areas were located to identify priority } \\
\text { transportation corridors to deliver fuel to affected areas. } \\
\text { Focused Case Study: (1) Identification of two likely rerouting paths across adjacent } \\
\text { NASA and USAF properties in the event that primary/sole access to Port Canaveral } \\
\text { were disrupted (highway bridge due to storm impacts); (2) engineering cost estimate to } \\
\text { determine investment required to improve roadway infrastructure along two identified } \\
\text { alternate routes to accommodate increased fuel truck traffic. }\end{array}$ \\
\hline Ashburn & $\begin{array}{l}\text { Provide the VDEM and the Virginia Homeland } \\
\text { Security Advisor with actionable analysis on the } \\
\text { critical dependencies and interdependencies of } \\
\text { lifeline infrastructure supporting the operations } \\
\text { of the Ashburn-area data cluster. }\end{array}$ & $\begin{array}{l}\text { The dependency analysis in the Ashburn RRAP focused on the analysis of data center } \\
\text { dependencies in the region of Ashburn. The study focused on utilities (i.e., electric } \\
\text { power, petroleum, water) distribution/transportation, with a specific emphasis on } \\
\text { communications and information technology dependencies. } \\
\text { The study led to the development of a cascading failures and restoration dependencies } \\
\text { visualization tool. }\end{array}$ \\
\hline \multicolumn{3}{|c|}{$\begin{array}{l}\text { a Abbreviations used in this table: EIA-Energy Information Administration; EIS-Environmental Impact Statements; ESRI-Environmental Systems Research Institute; } \\
\text { HSIP-Homeland Security Infrastructure Program; GIS-geographic information system; NASA-National Aeronautics and Space Administration; ORNL-Oak Ridge } \\
\text { National Laboratory; SCADA-supervisory control and data acquisition; SLOSH-Sea, Lake, and Overland Surges from Hurricanes; USAF-U.S. Air Force; VDEM-Virginia } \\
\text { Department of Emergency Management. }\end{array}$} \\
\hline
\end{tabular}




\begin{tabular}{|c|c|c|c|}
\hline RRAP & Electric Power & Natural Gas & Petroleum \\
\hline Maine & $\begin{array}{l}\text { Data: Energy Visuals; Platts, EIA }{ }^{\text {a }} \\
\text { Models: EPfast } \\
\text { Products: Outage areas; single-line diagrams; } \\
\text { substation consumption demand diagrams; } \\
\text { power plant peak production diagrams; GIS } \\
\text { mapping } \\
\text { Stakeholders: Central Maine Power; Maine } \\
\text { Governor's Energy Office }\end{array}$ & $\begin{array}{l}\text { Data: Platts; NPSMS } \\
\text { Models: N/A } \\
\text { Products: Mapping pipelines, power plants, } \\
\text { compressor stations; regional import/export } \\
\text { analysis; county- and sector-based } \\
\text { consumption analysis } \\
\text { Stakeholders: Bangor Gas Company; Maine } \\
\text { Natural Gas, LLC; Northern Utilities; Summit } \\
\text { Natural Gas of Maine; Trans- } \\
\text { Canada/Portland Natural Gas Transmission } \\
\text { Systems }\end{array}$ & $\begin{array}{l}\text { Data: Platts; NPSMS; FERC; AAR; EIA } \\
\text { Models: N/A } \\
\text { Products: Supply/demand balance; terminal } \\
\text { capacity diagrams; geospatial mapping } \\
\text { Stakeholders: City of Portland; City of South } \\
\text { Portland; Greater Portland Council of } \\
\text { Governments; Maine Department of } \\
\text { Transportation; Maine Emergency } \\
\text { Management Agency; Maine Geological } \\
\text { Survey; University of Maine Climate Change } \\
\text { Institute }\end{array}$ \\
\hline $\begin{array}{l}\text { Florida } \\
\text { Fuels }\end{array}$ & $\begin{array}{l}\text { Data: Energy Visuals; Platts, EIA } \\
\text { Models: EPfast } \\
\text { Products: Outage areas; single-line diagrams; } \\
\text { substation consumption demand diagrams; } \\
\text { power plant peak production diagrams; GIS } \\
\text { mapping } \\
\text { Stakeholders: Duke Energy; FDEM; Florida } \\
\text { Power \& Light; JEA; TECO }\end{array}$ & $\begin{array}{l}\text { Data: Platts; NPSMS } \\
\text { Models: N/A } \\
\text { Products: Mapping pipelines, power plants, } \\
\text { compressor stations; regional import/export } \\
\text { analysis; county- and sector-based } \\
\text { consumption analysis } \\
\text { Stakeholders: Chesapeake Utilities Corps, } \\
\text { Florida Public Utilities; Florida City Gas; } \\
\text { Florida Gas Transmission Co.; Florida Power } \\
\text { \& Light (natural gas power plants); } \\
\text { Gulfstream Natural Gas; TECO's Peoples Gas } \\
\text { System }\end{array}$ & $\begin{array}{l}\text { Data: Platts; NPSMS; FERC; AAR; EIA } \\
\text { Models: Gravity-based supply/demand } \\
\text { market segmentation model } \\
\text { Products: GIS mapping products showing } \\
\text { fuel terminal service areas, and shifts in } \\
\text { service areas due to disruption } \\
\text { Stakeholders: FDEM; JAXPORT: Port } \\
\text { Canaveral; Port Everglades; Port of Tampa; } \\
\text { and numerous facility owners (Marathon, } \\
\text { Buckeye, Transmontaigne, Chevron, etc.) }\end{array}$ \\
\hline Ashburn & $\begin{array}{l}\text { Data: ESRI; Navteq; Platts } \\
\text { Models: EPfast, Restore C } \\
\text { Products: Outage areas; single-line diagrams; } \\
\text { substation consumption demand diagrams; } \\
\text { power plant peak production diagrams; GIS } \\
\text { mapping; transition diagram; restoration } \\
\text { operations and time } \\
\text { Stakeholders: Dominion Power }\end{array}$ & N/A & $\begin{array}{l}\text { Data: Platts; ESRI; Navteq } \\
\text { Models: N/A } \\
\text { Products: Terminal capacity diagrams; } \\
\text { geospatial mapping } \\
\text { Stakeholders: Colonial; Fannon Petroleum; } \\
\text { Mirant Piney Point; Nustar; Plantation }\end{array}$ \\
\hline
\end{tabular}


Table A-3 - Transportation Models and Data

\begin{tabular}{|c|c|c|c|c|c|}
\hline RRAP & Air & Maritime & Pipeline & Rail & Road \\
\hline Maine & $\begin{array}{l}\text { Data: HSIPa Gold, } \\
\text { Navteq } \\
\text { Models: N/A } \\
\text { Products: GIS map } \\
\text { products of } \\
\text { facilities } \\
\text { Stakeholders: } \\
\text { Portland Jetport }\end{array}$ & $\begin{array}{l}\text { Data: HSIP Gold, Navteq } \\
\text { Models: N/A } \\
\text { Products: GIS map } \\
\text { products of facilities } \\
\text { Stakeholders: Casco } \\
\text { Bay Lines; Maine Port } \\
\text { Authority }\end{array}$ & $\begin{array}{l}\text { Data: HSIP Gold, Navteq } \\
\text { Models: N/A } \\
\text { Products: GIS map products } \\
\text { of facilities } \\
\text { Stakeholders: Trans- } \\
\text { Canada/Portland Natural } \\
\text { Gas Transmission Systems }\end{array}$ & $\begin{array}{l}\text { Data: HSIP Gold, Navteq } \\
\text { Models: N/A } \\
\text { Products: GIS map } \\
\text { products of facilities } \\
\text { Stakeholders: } \\
\text { St. Lawrence \& Atlantic } \\
\text { Railroad }\end{array}$ & $\begin{array}{l}\text { Data: HSIP Gold, Maine DOT } \\
\text { Culvert Adaptation Report, } \\
\text { Navteq } \\
\text { Models: N/A } \\
\text { Products: GIS map products } \\
\text { of facilities } \\
\text { Stakeholders: Maine DOT; } \\
\text { Maine Turnpike Authority }\end{array}$ \\
\hline $\begin{array}{c}\text { Florida } \\
\text { Fuels }\end{array}$ & $\begin{array}{l}\text { Data: HSIP Gold, } \\
\text { Navteq } \\
\text { Models: N/A } \\
\text { Products: GIS map } \\
\text { products of } \\
\text { facilities, fuel } \\
\text { supply to Orlando } \\
\text { Stakeholders: } \\
\text { Orlando } \\
\text { International } \\
\text { Airport (Greater } \\
\text { Orlando Aviation } \\
\text { Authority) }\end{array}$ & $\begin{array}{l}\text { Data: HSIP Gold, Navteq } \\
\text { Models: GIS map } \\
\text { products of facilities; } \\
\text { rerouting engineering } \\
\text { cost/feasibility study } \\
\text { Products: Port } \\
\text { accessibility/rerouting } \\
\text { study engineering cost } \\
\text { estimate } \\
\text { Stakeholders: JAXPORT; } \\
\text { Port Everglades; Port } \\
\text { Tampa Bay; Seaport } \\
\text { Canaveral; USCG }\end{array}$ & $\begin{array}{l}\text { Data: Platts; Florida SERT } \\
\text { Models: NGfast } \\
\text { Products: Mapping } \\
\text { pipelines, power plants, } \\
\text { compressor stations; } \\
\text { regional import/export } \\
\text { analysis; county- and sector- } \\
\text { based consumption analysis } \\
\text { Stakeholders: Florida City } \\
\text { Gas; Florida Gas } \\
\text { Transmission; Florida Power } \\
\text { \& Light; Gulfstream Natural } \\
\text { Gas; Tampa Pipeline Corp.; } \\
\text { TECO’s Peoples Gas System; }\end{array}$ & $\begin{array}{l}\text { Data: HSIP, FDOT, ESRI } \\
\text { Models: N/A } \\
\text { Products: GIS-based maps } \\
\text { of facility inundation due } \\
\text { to hurricane storm surge- } \\
\text { related flooding } \\
\text { Stakeholders: CSX; FEC; } \\
\text { Norfolk Southern }\end{array}$ & $\begin{array}{l}\text { Data: HSIP Gold; Navteq; } \\
\text { FDOT roadway GIS data; } \\
\text { FDOT/NBI bridge data; USAF } \\
\text { Cape Canaveral Air Force } \\
\text { Station; NASA Kennedy Space } \\
\text { Center pavement study } \\
\text { Models: RS Means civil } \\
\text { construction cost data } \\
\text { Products: Engineering } \\
\text { feasibility/cost study of } \\
\text { roadway upgrades } \\
\text { Stakeholders: FDOT; Florida } \\
\text { DEM; NASA Kennedy Space } \\
\text { Center; Port Canaveral; USAF } \\
\text { Cape Canaveral Air Force } \\
\text { Station }\end{array}$ \\
\hline Ashburn & $\mathrm{N} / \mathrm{A}$ & N/A & $\begin{array}{l}\text { Data: Platts; ESRI; Navteq } \\
\text { Models: N/A } \\
\text { Products: Mapping } \\
\text { pipelines } \\
\text { Stakeholders: Colonial; } \\
\text { Fannon Petroleum; Mirant } \\
\text { Piney Point; Nustar; } \\
\text { Plantation }\end{array}$ & N/A & N/A \\
\hline $\begin{array}{l}\text { a Abbreviat } \\
\text { FDOT-Flor } \\
\text { JAXPORT- } \\
\text { Response T }\end{array}$ & $\begin{array}{l}\text { d in this table: DE } \\
\text { artment of Transp } \\
\text { ville Port Authority }\end{array}$ & $\begin{array}{l}\text { partment of Emergency } \\
\text { n; FEC-Florida East Coa } \\
\text {-not applicable; NASA- }\end{array}$ & $\begin{array}{l}\text { gement; DOT-Department o } \\
\text { Iway; GIS-geographic inform } \\
\text { nal Aeronautics and Space Ad } \\
\text { oast Guard. }\end{array}$ & $\begin{array}{l}\text { sportation; ESRI-EnvironI } \\
\text { system; HSIP-Homeland } \\
\text { tration; NBI-National Brid }\end{array}$ & $\begin{array}{l}\text { al Systems Research Institute; } \\
\text { ity Infrastructure Program; } \\
\text { ventory; SERT-State Emergency }\end{array}$ \\
\hline
\end{tabular}


Table A-4 - Water Models and Data

\begin{tabular}{|c|c|c|}
\hline RRAP & Water & Wastewater \\
\hline Maine & $\begin{array}{l}\text { Data: HSIP, a Platts, Navteq } \\
\text { Models: N/A } \\
\text { Products: GIS mapping products - water pumping stations, water } \\
\text { treatment facilities } \\
\text { Stakeholders: Casco Bay Estuary Project; City of Portland; City of } \\
\text { South Portland; NOAA; Portland Water District; Town of Freeport; } \\
\text { Town of Saco Water District; USEPA }\end{array}$ & $\begin{array}{l}\text { Data: HSIP, Platts, Navteq } \\
\text { Models: N/A } \\
\text { Products: GIS mapping products-wastewater treatment facilities } \\
\text { Stakeholders: Casco Bay Estuary Project; City of Portland; City of } \\
\text { South Portland; NOAA; Portland Water District; Town of } \\
\text { Brunswick Sewer District; Town of Freeport; Town of Saco Water } \\
\text { District; USEPA }\end{array}$ \\
\hline Florida Fuels & $\begin{array}{l}\text { Data: HSIP, Florida SERT } \\
\text { Models: N/A } \\
\text { Products: GIS mapping products-water pumping stations, water } \\
\text { treatment facilities } \\
\text { Stakeholders: City of Fort Lauderdale (Port Everglades); JEA (Port } \\
\text { of Jacksonville/JAXPORT) }\end{array}$ & $\begin{array}{l}\text { Data: HSIP, Florida SERT } \\
\text { Models: N/A } \\
\text { Products: GIS mapping products-water pumping stations, water } \\
\text { treatment facilities } \\
\text { Stakeholders: City of Fort Lauderdale (Port Everglades); JEA (Port } \\
\text { of Jacksonville/JAXPORT) }\end{array}$ \\
\hline Ashburn & $\begin{array}{l}\text { Data: HSIP; ESRI; Loudoun Water \& County } \\
\text { Models: N/A } \\
\text { Products: GIS mapping products-Township Water Service; } \\
\text { Community System; Loudoun Central Service Area; Industrial Well; } \\
\text { Individual Well } \\
\text { Stakeholders: Fairfax Water; Loudoun Water }\end{array}$ & N/A \\
\hline
\end{tabular}


Table A-5 - Communications and Information Technology Models and Data

\begin{tabular}{|c|c|c|}
\hline RRAP & Water & Wastewater \\
\hline Maine & 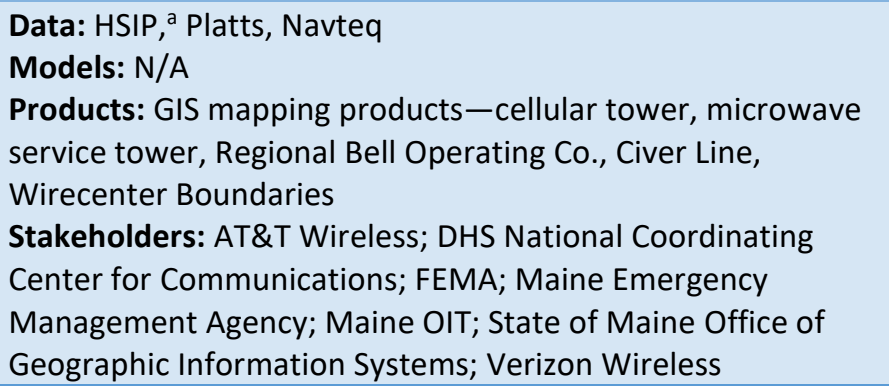 & $\begin{array}{l}\text { Data: HSIP, Platts, Navteq } \\
\text { Models: N/A } \\
\text { Products: GIS mapping products-cellular tower, microwave service } \\
\text { tower, Regional Bell Operating Co., Civer Line, Wirecenter } \\
\text { Boundaries } \\
\text { Stakeholders: AT\&T Wireless; DHS National Coordinating Center for } \\
\text { Communications; FEMA; Maine Emergency Management Agency; } \\
\text { Maine OIT; State of Maine Office of Geographic Information } \\
\text { Systems; Verizon Wireless }\end{array}$ \\
\hline Florida Fuels & $\begin{array}{l}\text { Data: Telecordia; FCC; HSIP } \\
\text { Models: N/A } \\
\text { Products: GIS mapping products-cellular tower, microwave } \\
\text { service tower, Wirecenter Boundaries } \\
\text { Stakeholders: AT\&T (BellSouth Telecommunications, Inc.); } \\
\text { FDEM }\end{array}$ & $\begin{array}{l}\text { Data: Telecordia; FCC; HSIP } \\
\text { Models: N/A } \\
\text { Products: GIS mapping products - cellular tower, microwave service } \\
\text { tower, Wirecenter Boundaries } \\
\text { Stakeholders: AT\&T (BellSouth Telecommunications, Inc.); FDEM }\end{array}$ \\
\hline Ashburn & $\begin{array}{l}\text { Data: Telecordia; FCC; HSIP, NCCIC } \\
\text { Models: NCCIC Modeling } \\
\text { Analysis: Wireline, Wireless, Emergency Services } \\
\text { Products: GIS mapping products-cellular tower, microwave } \\
\text { service tower, Wirecenter Boundaries Regional Bell Operating } \\
\text { Co., competitive local exchange carrier, personal } \\
\text { communication service, telecom hotels location and tenants } \\
\text { Stakeholders: AT\&T, Verizon, datacenters }\end{array}$ & $\begin{array}{l}\text { Data: Telegeography; Loudoun County Office of Economic } \\
\text { Development; HSIP } \\
\text { Models: N/A } \\
\text { Products: GIS mapping products-network map; fiber routes; } \\
\text { datacenters complex; } \\
\text { Stakeholders: Accenture; Airbnb; Akamai; Alcatel Lucent; Allied } \\
\text { Fiber; Amazon; Architect of the Capitol; Assa Abloy; AT\&T; Centers } \\
\text { for Disease Control and Prevention; CenturyLink, Code.org; Comcast; } \\
\text { COX Communications; Dominion Power; Dow Jones; DuPont Fabros } \\
\text { Technology; Equinix, Evoswitch; Excel Courier; Expedia; Fannon } \\
\text { Petroleum; Google; The Guardian; HTC; IAN LLC; InfraGard; NASA; } \\
\text { National Emergency Numbers Association; Netflix; Neustar } \\
\text { Networks; New York City Department of Transportation; Newsweek; } \\
\text { Nokia; Open IX; Pfizer; Primary Integrations; Raging Wire; SAP; } \\
\text { Schneider Electric; Siemens; Sprint; State of Arizona; SummitIG; } \\
\text { Swift; Uptime Institute; U.S. Food and Drug Administration Verisign; } \\
\text { Verizon; Visa; }\end{array}$ \\
\hline $\begin{array}{l}\text { Management; F } \\
\text { Computer Corpc } \\
\text { Communication }\end{array}$ & $\begin{array}{l}\text { his table: DHS-U.S. Department of Homeland Security; FCC-Fec } \\
\text { ederal Emergency Management Agency; GIS-geographic informa } \\
\text { AN-Instant Access Networks; N/A-not applicable; NASA-Nati } \\
\text { tion Center; OIT-Office of Information Technology; SAP-Systen }\end{array}$ & $\begin{array}{l}\text { mmunications Commission; FDEM-Florida Department of Emergency } \\
\text { tem; HSIP-Homeland Security Infrastructure Program; HTC-High Tech } \\
\text { onautics and Space Administration; NCCIC-National Cybersecurity and } \\
\text { cations, and Products. }\end{array}$ \\
\hline
\end{tabular}



Argonne

Global Security Sciences Division

9700 South Cass Avenue, Bldg. 203

Argonne, IL 60439-4854

www.anl.gov 